\title{
A NATIONAL PROGRAM FOR ENERGY-EFFICIENT MORTGAGES AND HOME ENERGY RATING SYSTEMS: \\ A BLUEPRINT FOR ACTION
}

\section{REVIEW DRAFT}

Final Report of the National Collaborative on Home Energy Rating Systems and Mortgage Incentives for Energy Efficiency

Prepared by the

National Renewable Energy Laboratory

Washington, D. C.

March 1992 
On September 16, 1991, the Solar Energy Research Institute was designated a national laboratory, and its name was changed to the National Renewable Energy Laboratory.

Prepared under Task No. AS135440.

\section{NOTICE}

This report was prepared as an account of work sponsored by an agency of the United States government. Neither the United States government nor any agency thereof, nor any of their employees, makes any warranty, express or implied, or assumes any legal liability or responsibility for the accuracy, completeness, or usefulness of any information, apparatus, product, or process disclosed, or represents that its use would not infringe privately owned rights. Reference herein to any specific commercial product, process, or service by trade name, trademark, manufacturer, or otherwise does not necessarily constitute or imply its endorsement, recommendation, or favoring by the United States government or any agency thereof. The views and opinions of authors expressed herein do not necessarily state or reflect those of the United States government or any agency thereof.

Printed in the United States of America 


\section{Preface}

This Review Draft reports findings and recommendations of the National Collaborative on Home Energy Rating Systems and Mortgage Incentives for Energy Efficiency. The U.S. Department of Energy, in cooperation with the U.S. Department of Housing and Urban Development, formed this National Collaborative as a National Energy Strategy initiative. Participating in the Collaborative were representatives of the primary and secondary mortgage markets, builder and remodeler organizations, real estate and appraiser associations, the home energy rating system industry, utility associations, consumer and public interest groups, state and local government interest groups, and environmental organizations. The Collaborative's purpose was to develop a voluntary national program encouraging energy efficiency in homes through mortgage incentives linked to home energy ratings.

The National Collaborative wrote A Blueprint for Action, which was published by the National Renewable Energy Laboratory (NREL).

A companion volume to this one, Going National with HERS and EEMs: Issues and Impacts (NREL/TP261-4706), provides technical documentation to the Collaborative's efforts. Also published by NREL, it contains a collection of 55 technical issue papers and 13 special papers prepared by the members of the Collaborative's Consensus Committee and Technical Advisory Committees. In addition, Going National contains a bibliography and glossary, which were prepared by Collaborative members and staff.

The valuable contributions of the Collaborative's members, those who served on technical committees, and staff are acknowledged. Without their dedication and commitment to a challenging task, the accomplishments reflected in this report would not have been realized. 


\section{Executive Summary}

Cost-effective energy efficiency technologies ${ }^{*}$ exist today to reduce dramatically the $\$ 100$ billion we spend each year on energy for our nation's housing. However, adoption of these technologies has been far slower than would be economically best for our nation and for individuals. One reason is that builders and home buyers have a strong tendency to minimize the "up-front" cost of a residential property, even at the expense of future savings. Mortgage loan practices reinforce this tendency. They fail to consider the lower total cost of owning an energy-efficient home with energy expenses are added to mortgage and tax payments.

One of the goals of the National Energy Strategy, recently developed at the direction of President Bush, is to counteract this tendency by developing reliable methods for rating the energy performance of residences and by encouraging mortgage-lending practices that fully reflect the value of lower energy operating costs. In response to that call for action, the U.S. Department of Energy, in cooperation with the U.S. Department of Housing and Urban Development, convened the National Collaborative on Home Energy Rating Systems and Mortgage Incentives for Energy Efficiency. The National Collaborative comprised members representing 25 organizations in the housing, mortgage finance, and energy supply industries, along with state and federal government, federally chartered financial institutions, and public interest organizations. Four technical advisory committees supported their work.

The mission of the National Collaborative was to reach a consensus on a voluntary national program that will link credible home energy rating systems with mortgage incentives for energy-efficient housing. A Blueprint for Action reports on the National Collaborative's findings and recommendations for creating such a program.

Widespread availability of energy-efficient mortgages (EEMs), teamed with accurate home energy rating systems (HERS), would make it easier and more affordable for Americans to live in energy-efficient homes. In fact, the Joint Center for Housing Studies has estimated that 250,000 more U.S. families could become first-time homeowners each year with EEMs. And the benefits to the environment of increasing the energy efficiency of the nation's housing stock would be significant.

In theory, a national EEM program would make available home mortgages that take into account the energy cost savings of the home. Home buyers could apply for EEMs when purchasing an energyefficient home or when they are buying an existing home and planning to make immediate energy improvements to it. EEMs would have more favorable terms and qualifying conditions than conventional

\footnotetext{
" Energy efficiency" is intended to include both energy efficiency measures (such as insulation and lowemissivity windows) and renewable energy technologies (such as passive solar design and solar domestic hot water systems), the use of which reduces a home's consumption of utility-supplied energy.
} 
loans. Supporting the EEMs, a reliable HERS allows both the lenders and the home buyers to be confident of the predicted energy savings.

EEMs and HERS are not new. However, EEMs have not been widely used because most buyers and many lenders are not aware of them. Also, lenders are not completely confident of the various EEM programs. Extra paperwork, lack of uniformity among EEM programs, and uncertainty about promised energy cost savings make lenders reluctant to use EEMs. In addition, lenders usually do not have access to a credible HERS program to determine energy cost data.

The members of the National Collaborative examined these issues and worked hard to hammer out a strategy to deliver an effective EEM program linked to voluntary HERS. There was broad consensus on the actions that can be taken immediately to set the stage for the program:

- Develop common standards for EEMs among the five federal agencies and federally chartered financial institutions: the Federal National Mortgage Association (Fannie Mae), the Federal Home Loan Mortgage Corporation (Freddie Mac), the Federal Housing Administration (FHA), the Department of Veterans Affairs (DVA), and the Farmers Home Administration (FmHA)

- Review the procedures of government programs and government-chartered institutions to remove any unnecessary barriers to implementing EEMs and simplifying the loan process

- Develop training and promotional programs to educate lenders, builders, real-estate professionals, appraisers, and consumers about EEMs

- $\quad$ Collect and analyze data from existing EEM programs on use patterns, default rates, and other factors.

When considering the design and implementation of HERS, the National Collaborative members concluded that the following steps should be taken:

- Develop a reliable, accurate, nationally uniform HERS program that could be used on a voluntary basis

- Implement HERS through state and local programs

- Train appraisers, real-estate personnel, energy raters, and others to use the system

- Institute quality control mechanisms for HERS.

The National Collaborative members agreed on several desirable characteristics of a national EEM program, including:

- All housing will be financed in the program

- The underwriting process will adequately recognize the reduced operating costs of energy-efficient housing

- Mortgage financing of both energy-efficient construction and improvements will be permitted

- $\quad$ Lenders will be indemnified against any added risk of borrower default

- $\quad$ Lenders will be able to use HERS to provide a reliable technical basis for allowing underwriting of mortgage loans by providing energy cost savings information to lenders. 
However, National Collaborative members were not able to reach consensus on some specific provisions of a national EEM program, such as how energy-efficiency improvements or construction costs should be reflected in the mortgage or how to incorporate energy cost savings into the procedures used to qualify people for EEMs. On these points, members agreed to disagree. A number of nonlending members advanced a concept for EEM characteristics; mortgage-lending members explained their concerns with the concept. Both sides of these issues are discussed in A Blueprint for Action.

The National Collaborative, through a consensus-building process, has constructed concepts that can link home financing to a successful national program of home energy rating systems. Collaborative members have progressed in understanding each other's needs and concerns that otherwise may have been barriers to creating a national program. Most important, the process has generated a momentum that can mold a successful program to help more people own energy-efficient homes.

Much remains to be done to fully develop, promote, and implement a national program of energyefficient mortgages linked to voluntary home energy rating systems. Many of the report's assumptions and goals need to be carefully tested to provide relevant data that will allow the program to have its maximum impact. These data will provide the basis for completing the unfinished business outlined in this report. But the need for data does not hinder action. Member organizations will review and comment on this Review Draft, which will also be made available for public comment. Implementation strategies will be further developed and tested, both for energy-efficient mortgages and for home energy rating systems. A Blueprint for Action will be revised to reflect the comments of member organizations and the public. 


\section{CONTENTS}

Chapter One: Introduction $\ldots \ldots \ldots \ldots \ldots \ldots \ldots \ldots \ldots \ldots \ldots \ldots \ldots \ldots \ldots \ldots \ldots$

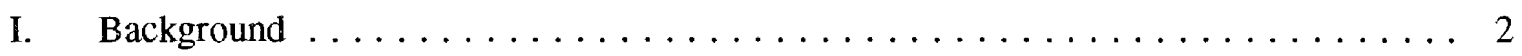

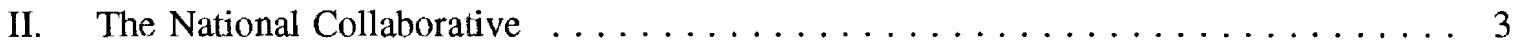

III. A Blueprint for Action . . . . . . . . . . . . . . . . . . 4

Chapter Two: Linking HERS and EEMs $\ldots \ldots \ldots \ldots \ldots \ldots \ldots \ldots \ldots \ldots \ldots$

Chapter Three: Energy-Efficient Mortgages $\ldots \ldots \ldots \ldots \ldots \ldots \ldots \ldots \ldots \ldots$

I. Characteristics of a Proposed Program upon Which There Was Full Consensus . . . . 8

II. Consensus Agreements on EEM Issues and Recommended Actions . . . . . . . . . 9

III. Specific Characteristics of an EEM Program Advanced by a Number of

Nonlending Members . . . . . . . . . . . . . . . . . . . . . 12

IV. The Mortgage-Lending Members Respond $\ldots \ldots \ldots \ldots \ldots \ldots \ldots \ldots$

Chapter Four: Home Energy Rating Systems $\ldots \ldots \ldots \ldots \ldots \ldots \ldots \ldots \ldots$

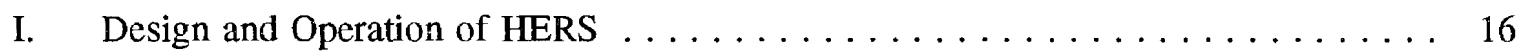

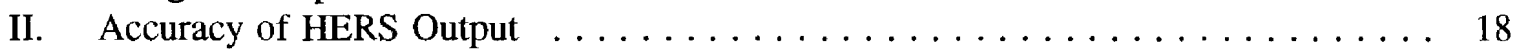

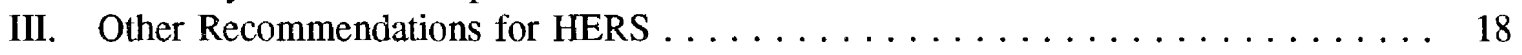

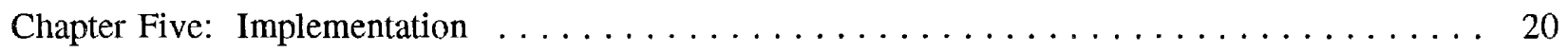

Chapter Six: Conclusion $\ldots \ldots \ldots \ldots \ldots \ldots \ldots \ldots \ldots \ldots \ldots \ldots \ldots \ldots \ldots \ldots \ldots$

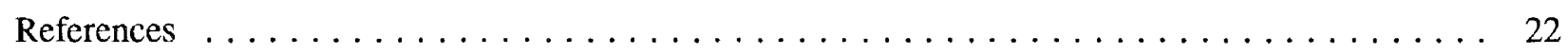

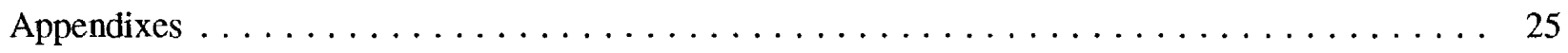

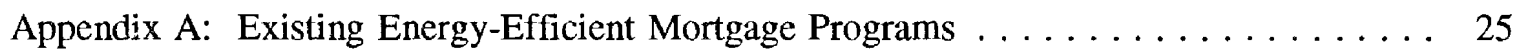

Appendix B: Members of the National Collaborative . . . . . . . . . . . . . . 29

Appendix C: Assigned Issues for the Technical Advisory Committees . . . . . . . . 33

Appendix D: National Collaborative Schedule . . . . . . . . . . . . . . 39

Appendix E: Acronyms . . . . . . . . . . . . . . . . 41

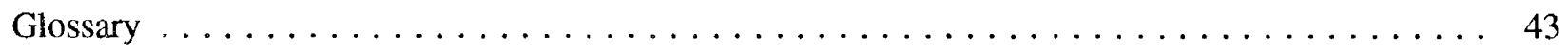




\section{Chapter One: Introduction}

Americans share the belief that their housing should be affordable, comfortable, and energy efficient. But, research has shown that the level of investment in energy efficiency in housing is less than that which is economically justified. Two major barriers limit investment in home energy efficiency. First, energy efficiency represents increased front-end cost, either as a home is first built or as an existing home is later improved. It is a long-term investment that must be financed. Second, there are insufficient market data to fully understand the value of energy efficiency in housing.

In recent years, growing attention has been given to two concepts that can help overcome these barriers-home energy rating systems, or HERS, and energy-efficient mortgages, or EEMs. HERS provide objective, standardized information on the energy performance of homes, analogous to miles-per-gallon ratings on automobiles or EnergyGuide labels on appliances. And EEMs provide a financing mechanism for energy efficiency. They allow a buyer of an energy-efficient home to qualify for a higher mortgage, using the future savings in energy costs to afford higher mortgage payments. EEMs may also be used to finance energy-saving improvements to existing homes, as part of the primary mortgage, at the time of purchase or refinance.

Expanded use of HERS could stimulate increased use of energy-efficiency and renewable energy technologies ${ }^{1}$ by making energy efficiency a more qualified, visible, and recognized attribute as homes are designed, built, bought, and improved. It would facilitate informed decision making. At the same time, expanded EEM activity will encourage home builders and owners to invest in energy-saving features without worrying that they are making their properties less affordable. HERS and EEMs have the potential to be closely linked. Energy cost estimates generated by a reliable HERS can be valuable information for those underwriting and insuring EEMs. Increased use of HERS for this purpose could help to speed the institutionalization of HERS and EEMs in the housing market.

Recognizing the potential for HERS and EEMs to stimulate home energy efficiency, the U.S. Department of Energy (DOE), in cooperation with the U.S. Department of Housing and Urban Development (HUD), initiated the National Collaborative on Home Energy Rating Systems and Mortgage Incentives for Energy Efficiency. The National Collaborative was created to prepare A Blueprint for Action, which is intended to extend the benefits of HERS and EEMs throughout the United States.

\footnotetext{
"Energy efficiency," as used throughout this document, is intended to include both energy-efficiency measures (such as insulation and low-emissivity windows) and renewable energy technologies (such as passive solar design and solar domestic hot water systems), the use of which reduces a home's consumption of utility-supplied energy.
} 


\section{Background}

HERS and EEMs are not new. Numerous HERS ${ }^{2}$ and energy-efficiency certification programs ${ }^{3}$ have been started in the United States. For a variety of reasons, many have ceased to exist. Others have persevered and continue to operate with varying degrees of market penetration. They are sponsored by a number of different types of organizations with varying goals and program designs. Some examples follow.

- The Energy Rated Homes of America organization has programs in Alaska, Arkansas, Iowa, Rhode Island, Vermont, Virginia, and West Texas.

- Several states are beginning HERS programs, including Arizona, California, Colorado, Mississippi, Missouri, Nebraska, New York, and South Carolina.

- The cities of Fort Collins, Colo., and Austin, Tex., have rating programs.

- The "Good Cents" and "Super Good Cents" certification programs are supported by almost 300 utilities, especially in the South and the Pacific Northwest.

Energy-efficient mortgages have been available for more than 10 years. In the early 1980 s, the five federal mortgage agencies and federally chartered financial institutions announced their willingness to buy, guarantee, or insure EEMs-Fannie Mae, Freddie Mac, FHA, DVA, and FmHA. ${ }^{4}$ Appendix A gives a brief description of the existing EEMs programs. In a number of locales, HERS or energy certification programs have been approved as a means to access EEMs. In other areas, EEMs are sometimes used without a HERS basis.

However, despite the availability of both HERS and EEMs, the programs have been underutilized. Few buyers and lenders are aware of the EEM option. For lenders, it often is seen as representing additional paperwork. There is a lack of uniformity in the five different national EEM programs. Primary and secondary lenders are unsure of the reliability of the promised energy savings. There are limited data on the relationship between energy performance and housing values. And because homeowners are unaware of EEMs and do not inquire about them, this is perceived as a lack of market interest.

\footnotetext{
${ }^{2}$ HERS measure and rate on a scale the relative energy efficiency of any house, regardless of age, efficiency, or fuel use. The rating is based on the thermal performance of the building envelope and the heating, ventilating, and air conditioning (HVAC) system and is obtained by an on-site inspection and calculations. HERS calculations include estimates of annual energy performance and costs and recommendations for cost-effective energy-efficiency improvements.

${ }^{3}$ A pass/fail home energy-efficiency rating system, or "certification program," is typically operated by utilities, home builders' organizations, or not-for-profit organizations. Energy- efficiency standards for these programs are developed using local building characteristics, construction practices, and climatic conditions. They usually include thermal envelope efficiency criteria and space conditioning efficiency criteria. Certification programs generally rely on a specified inspection/verification process to ensure rating consistency. Houses either pass or fail the inspection for energy efficiency.

${ }^{4}$ Federal National Mortgage Association, Federal Home Loan Mortgage Corporation, Federal Housing Administration, Department of Veterans Affairs, Farmers Home Administration.
} 
As a result, the potential national benefits of HERS and EEMs are not being realized. The benefits could include:

- An increase in the market penetration of energy-efficient new homes and energy improvements of existing homes

- A significant decrease in the estimated energy use by participating new and existing homes

- An increase in the number of families that could qualify as first-time homeowners by 250,000 each year ${ }^{5}$

- A significant reduction in environmental pollution.

Because of these potential benefits, HERS and EEMs have received the growing attention of the Administration and of Congress. The National Energy Strategy, issued in February 1991, states:

To encourage the more efficient use of mortgage financing for energy efficiency, the Departments of Energy and of Housing and Urban Development will increase financial and technical support to develop and encourage the voluntary acceptance of efficiency ratings and their use in home financing. After at least 5 years of support for voluntary adoption, it will be required that information on energy efficiency and information on the available mortgage financing options be provided to home buyers prior to sale. ${ }^{6}$

Congress endorsed the use of energy-efficient mortgages in the National Affordable Housing Act of 1990, which directs HUD to develop a uniform plan to make housing more affordable through mortgage financing incentives for energy efficiency. HUD intends to draw on the recommendations of the National Collaborative in meeting that Congressional directive.

\section{The National Collaborative}

The National Collaborative's members represent 25 organizations and interests which, working together, can make HERS and EEMs a national reality. The members represent states, mortgage lenders, builders, remodelers, public and environmental interests, utilities, and existing HERS programs. For a list of National Collaborative members, see Appendix B.

The National Collaborative was supported by four Technical Advisory Committees (TACs) in the subject areas of EEMs, HERS, Implementation, and Awareness. The Collaborative Consensus Committee (CCC) defined issues that it wanted the TACs to address. ${ }^{7}$ All of the technical issue papers prepared by

${ }^{5}$ Joint Center for Housing Studies 1986.

${ }^{6}$ U.S. Department of Energy 1991/1992, page 11.

${ }^{7}$ Appendix $\mathrm{C}$ lists the issues assigned to the four TACs by the Collaborative Consensus Committee (CCC). The TACs were responsible for providing technical recommendations to the CCC; the CCC was responsible for the final technical decisions and policy formulations as they are reflected in $A$ Blueprint for Action. In this document, the term "National Collaborative" (or "Collaborative") is used to stand for the CCC. 
these TACs, as well as special papers written by members of the CCC and others as part of the Collaborative process, are available in a separate volume, Going National with HERS and EEMs: Issues and Impacts, The Collected Papers of the National Collaborative. ${ }^{8}$

The first meeting of the National Collaborative was held March 26, 1991. Since then, Collaborative members have taken part in an intensive series of 10 meetings to prepare $A$ Blueprint for Action, plus numerous TAC and special subcommittee meetings and caucuses. ${ }^{9}$ The National Collaborative included participants with sharply different perspectives on some issues. Every statement included in $A$ Blueprint for Action required the concurrence of every individual participant in the Collaborative. Yet in only one area-the EEM program-members "agreed to disagree" on some of the provisions of a national program. But even here, there was a broad consensus on many actions that can be taken immediately while the parties work together to clarify some of the features of the national effort.

\section{A Blueprint for Action}

A Blueprint for Action is a compilation of the findings and recommendations of the National Collaborative regarding steps to be undertaken to establish a national EEMs/HERS program. With regard to EEM recommendations, a few areas of specific disagreement are clearly labeled as such.

The proposed "national program" consists of two main aspects: (1) revisions to current EEM programs with a goal of making them more user friendly, uniform, and substantive - and hence more effective; and (2) a national certification system to ensure the technical credibility of HERS programs to be used in conjunction with EEMs. A number of guidelines that local and state HERS programs would have to meet to attain certification as part of a voluntary national program are outlined. HERS programs not wishing to be part of the national EEM/HERS system would not be required to meet any of these guidelines.

This document consists of chapters on linking HERS and EEMs, characteristics of EEMs, characteristics of HERS, and implementation. The recommendations of the Collaborative regarding the linked EEMs/HERS program are described in Chapter 2. Chapter 3 characterizes an EEM program. It also presents characteristics of an EEM program presented by a number of nonlending members of the Collaborative, followed by the mortgage-lending representatives' response. Chapter 4 presents the consensus agreements on the characteristics that HERS programs would have to meet to be part of a national EEMs/HERS program. The document concludes with chapters on implementation strategies for

\footnotetext{
${ }^{8}$ This report (NREL/TP-261-4706) is available through the National Renewable Energy Laboratory, 1617 Cole Blvd., Golden, CO 80401.

${ }^{9}$ Appendix D shows the meeting schedule.
} 
linking EEMs and HERS, and the Collaborative's conclusions. Other supporting materials are included as appendixes.

A Blueprint for Action represents the final product of the first phase of discussions of the National Collaborative on these topics. Much further work is called for throughout the document, reflecting the view of the Collaborative that many specifics of a national program remain to be defined. 


\section{Chapter Two: Linking EEMs and HERS}

The goal of a national EEMs/HERS program is to promote energy efficiency in housing through a voluntary program that takes energy cost savings into account in the underwriting of mortgage loans. A national system will consist of compatible mortgage programs that are user friendly and readily available in the marketplace. These programs will rely on nationally consistent, technically credible HERS programs.

To achieve these goals, a national EEMs/HERS program must incorporate the following principles $^{10}$ :

1. It will apply to new and existing, energy-efficient and energy-inefficient housing.

2. The underwriting process will adequately recognize energy efficiency in making loans.

3. It will permit mortgage financing of energy-efficient construction and improvements.

4. It will indemnify lenders against added loss, if any, from borrower default.

5. It will provide a reliable technical basis to allow underwriting of mortgage loans by providing the energy cost savings information to the lender.

This report examines EEMs/HERS issues discussed by the National Collaborative and possible ways of achieving the stated goals. The Collaborative has agreed upon a number of important issues. These agreements expedite the linkage of EEMs with HERS. They include the following:

1. Development of common standards among Fannie Mae, Freddie Mac, FHA, DVA, and FmHA. The mortgage-lending community will work to develop common standards, forms, and practices to make EEM programs more user friendly.

2. Removal of barriers. Each government agency and federally chartered financial institution will review its existing program to remove any unnecessary barriers and simplify the EEM process.

3. Sponsorship of educational, training, and promotional programs. Lenders, appraisers, realestate sales and marketing professionals, energy raters, and others will require training in using EEMs and HERS; consumer awareness of EEMs/HERS will need to be increased. Each government agency and federally chartered financial institution will promote the use of EEMs by increasing training and educational programs about them.

4. Collection of data. The agencies and federally chartered financial institutions will take steps to collect information on their EEM programs and provide the data to a single organization for further analysis and reporting.

5. Analysis of existing EEMs/HERS data to evaluate loss experience. In addition, the agencies and federally chartered financial institutions will take data that may currently exist concerning homes that have had an energy rating and been financed with an EEM, and cross-check those

\footnotetext{
${ }^{10}$ These are the themes that are more fully developed in the report.
} 
loans against the records of the loans they currently hold to generate current financial performance information.

6. Development of a nationwide HERS program. DOE, in concert with the HERS industry, will initiate the process to develop national guidelines for HERS programs that provide credible information for the mortgage-lending process and other housing-market participants.

7. Assurance of quality control for HERS. The HERS community will help assure credibility by developing and adopting effective quality-control programs governing software, personnel, data collection, labeling, and other components of HERS programs.

The National Collaborative recognizes that the EEM effort is in its formative stages. There is a great deal of data still to be collected and analyzed, and the risks are not fully quantified.

As noted earlier, Chapter 3 presents characteristics of a national EEM program and Chapter 4 presents characteristics of a national HERS program. A linked EEMs/HERS program is discussed further in the Implementation and Conclusion chapters. 


\section{Chapter Three: Energy-Efficient Mortgages}

\section{Characteristics of a Proposed EEM Program upon Which There Was Full Consensus}

An effective national EEM program requires that the major lending institutions establish a consistent and explicit mechanism for recognizing energy efficiency in the mortgaging process. After extensive analysis and discussion, the National Collaborative reached consensus on the following recommendations concerning the EEM program.

1. The EEM program should have the following general characteristics:

a. An EEM program should be available from all major lending and insuring agencies and for all regular types of mortgages.

b. An EEM program should be as uniform as practical among different types of mortgages and different lending and insuring agencies.

c. An EEM program should be simple to apply administratively. The forms, policies, procedures, rating systems, and so on should be uniform and as streamlined as possible.

d. Alternative approaches may be used, provided that they have characteristics that are at least equivalent to these provisions.

2. Lenders should be adequately indemnified for any additional risk assumed in financing the cost of energy-efficiency improvements.

3. An applicant for a loan to purchase or refinance a home that meets a nationally recognized voluntary consensus standard ${ }^{11}$ should be eligible for recognition of energy cost savings in the mortgage-qualifying process. Examples of such recognition could include increasing qualifying ratios $^{12}$ or adjusting one of the components used to calculate the ratios.

\footnotetext{
${ }^{11}$ There needs to be a nationally recognized consensus standard as a reference for the purpose of determining efficient versus inefficient housing and as a factor in calculating energy cost savings that can be recognized in the EEMs. Additional work will be required to arrive at a reference and to assess its impact with respect to mortgages. A distinction between "reference" and "baseline," for the purposes of clarity, is appropriate.
}

1. Reference is the nationally recognized consensus standard that determines energy efficient versus energy inefficient.

2. Baseline is the point from which energy cost savings are measured. For inefficient homes, when the intent is to make cost-effective energy-efficiency improvements, the baseline is the house as it actually exists. For efficient homes, the baseline will be an as yet undefined point that has an agreed-upon economic relationship to the reference.

${ }^{12}$ Qualifying ratios are percentage ratios that compare borrowers' anticipated monthly fixed housing expense and total monthly obligations to borrowers' stable monthly gross income for the purpose of evaluating the likelihood of meeting expenses involved in home ownership. 
4. A qualified applicant for a standard mortgage may qualify for an energy-efficient mortgage covering the cost of improvements that are determined to be cost effective by a nationally recognized HERS. The EEM program may include a maximum cost limit for allowed improvements. ${ }^{13}$

5. Underwriting procedures should recognize energy cost savings separately from compensating factors.

At the same time, lenders, real-estate sales and marketing professionals, and appraisers should work to raise public awareness of home energy efficiency and of related opportunities in the mortgagelending process. Also critical, of course, is that a nationally consistent, technically credible home energy rating system be made widely available.

\section{Consensus Agreements on EEM Issues and Recommended Actions}

Following are the consensus agreements on eight sets of recommended actions with respect to EEM-related issues.

Potential Risk. There may be an unquantified additional risk to the mortgage-lending community ${ }^{14}$ from amortizing the full cost of energy improvements in mortgages. This is because:

1. Insufficient data have been collected on the performance of energy-efficient mortgages.

2. Current market conditions show that energy-efficiency items in a home have added little or no additional appraised value to the property. This may be because actual comparable market data for energy improvements may not be available.

3. Increased underwriting ratios and loan-to-value (LTV) ratios ${ }^{15}$ have been shown to increase borrower default risk in regular mortgages when considered by themselves.

\section{Recommended Actions for This Issue.}

1. For the short-run, government agencies and federally chartered financial institutions should review data that currently exist (to be obtained from organizations that currently rate homes and assist borrowers in obtaining EEMs) on mortgages that have been underwritten under their existing programs and determine whether such data are sufficient for a preliminary risk analysis to be performed. For the long-run, the mortgage-lending community should take steps to begin

\footnotetext{
${ }^{13}$ The limitation on the amount only refers to this specific context and is not intended to limit amounts for other improvements or in other situations.

${ }^{14}$ The term "mortgage-lending community" is used throughout this document to refer to the government agencies and government-sponsored enterprises of FHA, DVA, FmHA, Fannie Mae, and Freddie Mac, as well as individual lenders.

${ }^{15} \mathrm{LTV}$ ratio is the relationship between the amount of the mortgage loan and the appraised value of the security, expressed as a percentage of the appraised value (see Glossary).
} 
collecting data on mortgages underwritten using their respective EEM programs and, as noted earlier, provide data to a single organization for further analysis.

2. If EEMs are to be implemented prior to the full availability of data, the mortgage-lending community should be indemnified for any additional risk from amortizing the full cost of energy improvements in mortgages. This could be accomplished through tax incentives, tax credits, or by a third party acceptable to the mortgage-lending community, should such sources become available. If the added borrower risk of EEMs is accepted as not being significantly greater than non-EEMs, the default rates for non-EEMs can be used as the anticipated default rate to quantify indemnification guarantees to the mortgage investor/guarantor. An analysis should be conducted to ascertain total risk, to identify methods of reducing risk, and to determine the extent to which indemnification is appropriate.

Cost of Energy-Efficiency Improvements. The additional cost of making a home energy efficient may prevent a borrower from qualifying for a mortgage.

\section{Recommended Actions for This Issue.}

1. The National Collaborative agreed that projected energy cost savings should be used as a separate factor in calculating whether a borrower qualifies for an EEM.

2. There should not be a limit on the cost of energy-efficiency improvements as long as market value appraisals or investor/guarantor indemnification and proper underwriting standards are used.

3. A HERS should be implemented to support a broad-based EEM system.

4. The existing EEM programs-described in Appendix A-should stay in effect until they are revised.

Handling Energy Cost Savings in Lending. There was disagreement about how the cost of energy improvements should be considered in mortgage financing. In some geographic areas, there may be limited market data on which to determine the estimated market value (through an appraisal) of energy-efficient housing. ${ }^{16}$ The mortgage-lending community has stated that the value of the property in lending decisions should be based on appraised market value.

Recommended Action for This Issue. The National Collaborative recognized the issue of whether to increase the mortgage amount for cost-effective energy improvements in the absence of comparable data to support an estimation of the market value of the property with those improvements. The mortgage-lending community representatives have agreed to consider credit enhancements in the form of acceptable third-party indemnification to the investor/guarantor to the extent that the mortgage amount is increased to include cost-effective energy-efficiency improvements not based on appraised market value.

\footnotetext{
${ }^{16}$ There are often insufficient data to determine if the market will recognize the value of energy efficiency in a dollar-for-dollar increase in property value.
} 
Increased Downpayment. Adding energy-efficient improvements to a home may increase the amount of the borrower's downpayment. For some buyers, the downpayment is the limiting factor in housing affordability. Loan underwriting standards require a minimum downpayment. If the cost of the home is increased by the cost of the energy improvements, in some cases the amount of the downpayment goes up proportionally. Borrower default risk is highly correlated with the amount of equity, and, thus, the commitment a borrower has to the home. Consequently, an EEM may require a higher downpayment.

Recommended Action for This Issue. One method of overcoming this barrier would be to allow acceptable third-party organizations to provide a grant to the borrower for the incremental downpayment. Grants may improve borrowers' chances to buy energy-efficient homes or to make energyefficiency improvements.

Mortgage Limits and Improvement Costs. Maximum mortgage limits make it difficult to add the cost of energy improvements to mortgages that are already at or near the limit.

Recommended Action for This Issue. Mortgage limits are set by legislation. The Collaborative recommended that current law be modified to increase the maximum mortgage limits for all energyefficient mortgages. (Freddie Mac and Fannie Mae cannot support having their loan limits changed; however, other groups could support this.) For example, HUD provides that for improvements involving renewable energy technologies, the maximum mortgage limit can be increased by up to $20 \%$.

Complexity and Delay in EEMs. Barriers and complexities prevent primary lenders, builders, real-estate sales and marketing professionals, remodelers, and home buyers from using the EEM process.

\section{Recommended Actions for This Issue.}

1. Additional incentives would be helpful.

2. All agencies will review their existing programs in an effort to remove any unnecessary barriers and to simplify their processes.

3. Common standards and uniformity are recommended. As noted earlier, the agencies and federally chartered financial institutions should develop common standards, forms, and practices to make their respective EEM programs more user friendly.

Training Needs. There is insufficient training for lenders, real-estate sales and marketing prc :ssi nals, appraisers, and others in the process.

\section{Recommended Actions for This Issue.}

1. Each mortgage-lending agency and federally chartered financial institution should promote the use of EEMs by increasing training and educational programs.

2. The uniformity in standards, forms, and practices referenced above would assist lender training. Credible HERS Programs. To qualify for consideration in an EEM, the home energy ratings should have credibility in the lending community. 
Recommended Action for This Issue. A nationwide HERS program with credible standards and effective quality-control mechanisms should be the basis for a nationwide EEM program.

\section{Specific Characteristics of an EEM Program Advanced by a Number of Nonlending Members}

With regard to the specifics of the EEM program, there remain some areas of uncertainty and some disagreements among Collaborative members over the most effective or most desirable course to take. It was generally agreed that there should be a balance between incorporating characteristics into the mortgage process that would effectively encourage energy efficiency and, at the same time, protect the mortgage-lending community from potential additional risk. However, the Collaborative was unable to agree on certain characteristics. In the interest of framing certain relevant points for future reference, the Collaborative agreed to present one model advanced by a number of nonlending members of the Collaborative. Section IV presents a brief discussion of the issues raised by the mortgage-lending members in response.

To these nonlending members, an EEM means a mortgage on a residential property that recognizes the energy cost savings of an energy-efficient home. Such an EEM qualifies borrowers who would otherwise have qualified for a mortgage on a similar home without cost-effective energy-saving construction or improvement features. Therefore, an EEM would remove the mortgage barriers and disincentives to the purchase of energy-efficient homes and to making energy-efficiency improvements in existing homes.

These nonlending members advanced the concept that an EEM program should implement certain characteristics in specific ways. The elements of an EEM program they focused on included loan qualification for energy-efficient and inefficient homes, calculating the maximum loan available, downpayment assistance, maximum mortgage limits, and supplemental mortgage insurance.

Loan qualification for energy-efficient homes. An energy-efficient home is one that has been built or improved to at least a nationally recognized voluntary consensus energy performance standard. ${ }^{17}$ For an energy-efficient home, the basic debt-to-income qualifying ratio should be increased by $2 \%$. For homes that exceed the standard, the added monthly cost savings should be subtracted from the normal housing costs (principal, interest, taxes, and insurance, or PITI) before calculating the qualifying ratio.

Loans for improvements to inefficient homes. For cost-effective ${ }^{18}$ energy-efficient improvements to homes that do not meet the nationally recognized performance standard, the energy cost

\footnotetext{
${ }^{17}$ The exact standard will be determined at a later date.

${ }^{18}$ The exact definition of "cost effective" will be determined at a later date.
} 
savings resulting from the improvements should, at the purchaser's election, be subtracted from the PITI. The loan's total amount should be increased by an amount equivalent to the present worth of the capitalization of the energy cost savings that will be realized.

Calculating maximum loan amount. Mortgages are generally limited to a percentage of the appraised value, for example, $90 \%$ or $95 \%$. For cost-effective improvements to inefficient homes, the mortgage amount should be increased by the total cost of the energy-saving improvements after the home's appraised value has been determined and the base loan has been approved. However, the increase should be limited to an amount that, when amortized along with the mortgage, can be paid for by the monthly energy cost savings. And the money for the energy improvements should be put into escrow with the title company or other depository at closing.

For energy-efficient homes, conceptually the mortgage amount should be increased as described above. However, on new homes, this is difficult to compute. Therefore, the mortgage amount should be increased by an amount up to 5\% of the home's appraised value.

Downpayment assistance. Federal, state, or other public or private programs should develop programs to provide grants to home buyers to cover the additional downpayment for the incremental increase in the loan amounts described above. Private groups such as utility companies and home builder associations may be interested in establishing such programs. Lending institutions should accept the grant money as if it were the borrower's own funds.

Maximum mortgage limits. A mortgage on an energy-efficient home should be allowed to exceed the maximum mortgage limit in effect at the time by up to $5 \%$.

Supplemental mortgage insurance. To minimize any added risk of default to lenders for the added mortgage value of EEMs, the amount added to the mortgage for energy-efficiency features should be covered with supplementary mortgage insurance for five years.

\section{The Mortgage-Lending Members Respond}

The members of the National Collaborative who represented the mortgage-lending community (those involved in determining how credit is granted in the secondary mortgage market, which provided more than $\$ 453$ billion in mortgage financing in 1990) did not completely endorse or support the preceding suggested characteristics of an EEMs program (Section III).

As the primary risk takers in the real-estate finance process, the mortgage-lending members believed the adoption of certain of the suggested characteristics could expose the mortgage-lending community to additional risks and losses that are currently unknown and unquantified. This was unacceptable to those charged with maintaining the stability of the national mortgage market.

Within the spirit of the National Collaborative process, the mortgage-lending community members respected and appreciated the views expressed by those members of the National Collaborative who did 
not share in the mortgage risks associated with EEMs. However, it is important that concerns related to issues identified during the National Collaborative process be defined as those on which the National Collaborative did not reach consensus. These issues follow:

Property valuation. The value of a property used in the mortgage underwriting process must be based on the property's market value. Any increase in the value of a property due to an improvement (including energy-efficiency improvements) must be based on the market's response to the improvement itself-not its cost. Deviation from this fundamental appraisal approach to valuation exposes the mortgage-lending community to an additional risk of greater loss if the market does not recognize the entire cost of an improvement as a dollar-for-dollar increase in the property value.

Borrower qualification-income and expense considerations. The possibility that a borrower will experience lower energy costs in an energy-efficient house than in an energy-inefficient house is a factor that can be considered in the mortgage underwriting process. The extent to which a uniform, nationally recognized HERS will help estimate an average amount of expected energy cost savings for a specific house helps to estimate the possible impact for a given borrower. However, the possibility of lower energy costs is only one of the many factors that need to be evaluated in the mortgage underwriting process. Energy costs are not a fixed expense like the mortgage payment itself, property taxes, and insurance. In fact, energy costs vary greatly, depending on climate zone, weather conditions, and individual lifestyles.

The mortgage-lending community cannot accept the unknown level of default risk imposed by any formula approach to income qualification that assumes a theoretical reduction in fixed monthly mortgage payments based on an estimation of possible energy cost savings by the occupant/borrower. Such an approach would elevate the perception of possible energy cost savings to a level of significance in the mortgage underwriting process for which no empirical basis currently exists.

The mortgage-lending community supported the concept that the estimated energy cost savings may be used as an additional factor in calculating whether a borrower qualifies for a specific mortgage, rather than the use of some formula or factor that has no relationship to the actual energy costs and/or savings of a specific house. ${ }^{19}$

Supplemental mortgage insurance. For conventional mortgage loans, the use of supplemental mortgage insurance to cover any additional loss due to default may be unworkable for several reasons. First, although the use of insurance transfers the risk to a private mortgage insurance company, the lender must rely on the private mortgage insurer's ability to pay a claim. By adding more risk to the insurer's portfolio in the form of the supplemental insurance, the financial stability of the insurer is weakened. This could place the lender at greater risk. Second, the supplemental mortgage insurance coverage will increase the borrower's cost of obtaining a mortgage. This cost may need to be compared

\footnotetext{
${ }^{19}$ It should be noted that HERS rate specific houses.
} 
to the estimated energy cost savings for the home. Third, the insurance industry is regulated at the state level. Many state regulations prohibit mortgage insurers from issuing policies where the loan-to-value ratio exceeds $95 \%$.

If viewed individually, the suggested EEM characteristics may appear to be minor changes to mortgage program users and beneficiaries. However, when the suggested EEM characteristics are viewed in total, and within the context of the whole national mortgage market and its needs, they become unacceptable to the mortgage risk takers.

Each member of the mortgage-lending community must analyze and maintain EEM programs within the context of their respective roles and mortgage programs, while not losing sight of the needs of the national mortgage market. The members of the mortgage-lending community must balance the risks associated with the origination, purchasing, insuring, and guaranteeing of all mortgages, including EEMs, with the need to maintain financial stability and ensure the continuing availability of funds for the national mortgage market.

The mortgage-lending community will continue to work toward a uniform national program that will promote energy efficiency in housing. As progressive steps are taken to achieve this goal, the risks and losses will be evaluated. By taking incremental advances based on appropriate risk assessment, the nation's mortgage industry will remain sound in order to continue to offer mortgage financing opportunities. 


\section{Chapter Four: Home Energy Rating Systems}

A significant number of HERS have been established since 1980. Some have ceased to exist; others continue to operate. All have faced significant market obstacles. ${ }^{20}$

To a large degree, HERS in different locales have developed independently. This has resulted in many unique programs. Because no single HERS model exists, new programs continue to expend significant resources on research and development. The local variation in the programs makes it impossible to build a universal link between HERS and a national EEM program. Further, most HERS use different calculational approaches, or "tools," with little or no documentation of technical accuracy. In fact, technical standards for HERS have never existed. Lenders and others have questioned the reliability of energy-use and savings estimates generated by HERS.

A primary focus of the National Collaborative's HERS deliberations was to define a set of guidelines that would address the concerns of technical credibility. These guidelines deal with the basic design and operation of HERS programs and set accuracy standards that "certified" HERS programs must meet if they are to participate in the national program. The guidelines are also designed to promote uniformity among different HERS to facilitate a uniform link to a national EEMs/HERS program.

At the same time, care was taken to specify minimum features to allow local programs substantial flexibility to meet local needs. This approach recognized that the national effort should build upon existing local HERS and bring them into a national framework, or umbrella, rather than strive to create a single, nationally administered HERS.

The recommended guidelines are largely based on the desire for a EEMs/HERS link; however, they will also provide useful guidance for independent HERS programs. Only programs that wish to be certified under the national EEMs/HERS program would have to meet these guidelines.

The consensus findings of the National Collaborative follow. ${ }^{21}$

\section{Design and Operation of HERS}

The design and use of HERS tools should follow these principles.

Basic measure on which ratings should be based. The basic unit of measure should be total annual energy use in Btu/year by fuel type. The HERS calculation tool should be capable of converting these quantities to all commonly used normalization parameters.

\footnotetext{
${ }^{20} \mathrm{Cf}$. Vories and George 1991.

${ }^{21}$ The HERS TAC was notable among the Collaborative's four TACs in that it achieved a consensus recommendation on each of the 21 issues it was assigned. While not all of these recommendations were adopted by the CCC, they provide a useful guide to state-of-the-art technical thinking on HERS. As noted elsewhere, the full set of papers is available in Going National with HERS and EEMs: Issues and Impacts, The Collected Papers of the National Collaborative.
} 
Fuel neutrality. Fuel neutrality will be addressed by requiring verified HERS calculation tools to produce accurate energy-use and cost projections. Other issues relating to energy type should be decided at the state or local level.

Treatment of occupant behavior. To ensure consistency and credibility, a HERS calculation tool should rate the home using standardized occupancy assumptions. Those features of the home under control of the occupants - such as thermostat set points, removable lights and appliances, whole-house fans, and water-heater set points-will be assumed to be fixed in the rating calculation tool to account for occupant-related factors. The HERS calculation tool should incorporate average estimates for lifestyle parameters to account for average occupant behavior. The average estimates need to be as locationspecific as possible, and they need to be applied consistently.

Differentiation between new and existing housing. New and existing homes should not be differentiated, from a technical standpoint, in the calculation of energy use by HERS calculation procedures. In practice, specific HERS programs may offer different services with respect to new and existing homes.

Building types. HERS should be applicable to multifamily, single-family, and manufactured housing. A HERS calculation tool should be certified or verified for those building types it is intended to rate.

Home features measured by a HERS. A HERS calculation tool should provide the estimated annual energy performance of the building in Btu/year and dollars for fuel type. That number is composed of the energy use associated with the performance of the following:

- Thermal envelope

- Mechanical heating, ventilating, and air conditioning (HVAC) system

- External load controls ${ }^{22}$

- Hot water service

- Optional features, including hard-wired lights, major appliances and controls, and energystorage systems.

Specific recommended features to be included in HERS calculation tools remain to be defined.

Inclusion of innovative features. The certifying process for HERS tools would allow qualification according to the building types, features, and climate zones for which a local HERS calculation tool is intended. Certified HERS should also provide for alternative rating calculation tools when a simplified input tool cannot handle particular buildings, energy features, or new technologies. HERS should strive to keep pace with new technological developments by periodically upgrading its calculational tools.

\footnotetext{
${ }^{22}$ External load controls are fixed or movable shading elements (e.g., awnings, wing walls, overhangs, eaves, and shade screens) that control solar heat gain to exterior envelope components.
} 


\section{Accuracy of HERS Output}

All HERS must be capable of producing consistent and accurate ratings. There are two levels of accuracy. The first is the accuracy of the HERS calculation tool. The second is the accuracy of the entire delivered home energy rating system, including the energy inspection, the translation of energy-inspection information to input data, the recommended cost-effective energy-efficiency improvements, the standardized occupant and operating assumptions, field inspections, and the use of the HERS calculation tool to produce an energy and dollar estimate.

Accuracy of the HERS calculation tool. A HERS calculation tool should accurately project energy use in energy units and dollars. To be certified as an approved HERS calculation tool, calculational accuracy within a prescribed range relative to benchmark results from state-of-the-art detailed simulation models must be demonstrated (exact procedure to be developed). The acceptable range should be determined, recognizing the trade-off between accuracy, ease of use, cost of performing the rating, and the needs of the EEM.

Accuracy of the entire HERS system. To maintain certification under the national HERS umbrella, HERS would be required to collect data, such as short-term data, long-term submetering data, or utility bill data to verify overall quality control of the system and to allow periodic self-correction (data collection protocols to be developed).

Rater training and quality control. Rater training and qualification should include a mix of classroom and on-site training, concluding with certification by testing and demonstration of proficiency. HERS programs are responsible for quality control of their raters.

\section{Other Recommendations for HERS}

The National Collaborative made four other recommendations concerning a national HERS program.

HERS procedures for retrofits and renovations. For a HERS to qualify for the national program, its calculation tool's affiliated savings estimates need to take into account the potential interactive effect of the energy features on energy and cost savings.

Procedures for rating groups of new buildings. Building ratings should be permitted to be grouped when technically feasible, when quality control can be demonstrated, and when accuracy criteria will be met. Group ratings will reduce duplication of effort and cost and will provide a common basis for comparing homes. Group ratings are most appropriate when applied to the same home design built multiple times on comparable sites, or when applied consistently within the criteria of a certification program. Homes can be spot-checked to verify the accuracy of the rating; each home would not have to be individually rated. 
Allowance of different rating approaches. A single rating method and scale should be the basis for linking EEMs and HERS as an element of the national program. A "rating method," as used here, is the equation and associated inputs that describe the relationship of a rating to an amount of energy use, energy cost, or other measure of efficiency. Local systems should be able to use any designation they choose to present rating information to users within their service area. A single rating method would facilitate linkage to a uniform national EEMs/HERS program. Further study is recommended to determine the form, parameters, and inputs of the rating method.

Requirements for re-rating of homes. Homes for which EEM financing is desired may need to be re-rated at the time of sale or refinancing if the lenders so require. If the rated home's features remain unchanged and the rating scale for that locale remains the same, the home may not need to be rerated.

National data base. Lack of data is the largest hurdle to setting up a successful national EEMs/HERS program. Each HERS program in each jurisdiction should keep accurate records of every house rated. There needs to be a national data base on energy-rated homes and EEM homes. A national program should develop a set of guidelines for minimum requirements for state and local data bases to allow data retrieval and reporting to the national data base. 


\section{Chapter Five: Implementation}

During 1991, the National Collaborative was able to accomplish a great deal; yet much more remains to be done to fully develop, promote, and implement a national EEMs/HERS program.

For some of the following items, participant groups can take action on their own to make further progress. Most items, however, will require a more organized effort. DOE, in collaboration with HUD, should take the initiative to prioritize the following tasks and take appropriate actions to make progress in each of the listed areas. These actions could include, among other things, public meetings, conferences, appointment of one or more implementation task groups, and the retention of contractors.

Included among the unfinished business is the following:

- Distribution of A Blueprint for Action for public comment

- Revision of A Blueprint for Action based upon the substance of the public comment

- Further development of mechanisms for program implementation, including mechanisms to develop and manage the following:

- Technical clearinghouse

- Information clearinghouse

- HERS accreditation system

- Rater credentialing system

- Data collection system

- Data analysis program

- Quality assurance program

- A business plan

- A public information and education program

- Labeling criteria

- The HERS rating method

- A nationally recognized consensus standard to define energy efficiency

- An adequate indemnification mechanism

- Demonstration programs

- Common standards, forms, and practices by the agencies and enterprises.

A report summarizing progress made during 1992 should be prepared at the end of 1992. 


\section{Chapter Six: Conclusion}

The National Collaborative, through a consensus-building process, has defined concepts for linking home financing to a successful national program of home energy rating systems. Substantial progress has been made in educating all National Collaborative members on needs of both the energy rating and the home financing industries. Most importantly, a momentum has evolved that has the potential for results and ultimate realization of the National Collaborative's goals.

A responsibility of the members of the National Collaborative is to sustain this momentum, further integrate interests and viewpoints, and foster continued constructive communications among key interest groups. A strategy for meeting this responsibility is to sponsor demonstration and field testing of certain assumptions and program goals outlined in A Blueprint for Action. These tests would be carefully planned and focused, highly controlled, and designed to maximize input to the national program and provide relevant data to the future deliberations of the mortgage-lending community and for further program development.

The secondary mortgage-market agencies should work directly with local HERS/EEMs program administrators in a limited pilot program to test the proposed EEM program that emerges from the National Collaborative. Elements of such a pilot program could include, but would not be limited to:

- Elements designed to encourage the program's use and overcome hurdles (incentives could be one of these elements)

- Guidelines to allow ease of financing energy-efficient improvement and construction features and recognition of energy-efficient properties, while at the same time, indemnifying lenders from risk

- Sponsorship of educational, training, and promotional programs in coordination with the local HERS/EEMs administrator

- A built-in mechanism to allow mid-course corrections for program fine-tuning

- An established goal for the pilot program against which to measure success

- Collection of data relevant to the evaluation of the pilot program.

The National Collaborative hopes that the momentum initiated during its 1991 deliberations will result in numerous organizations effectively carrying forward the development of HERS linked to a national program of amortizing the cost of energy improvements in housing through mortgage financing. 


\section{References}

Joint Center for Housing Studies of the Massachusetts Institute of Technology and Harvard University. May 1986. The Effect of the Shelter Industry Energy Rated Homes ${ }^{T M}$ System on Homeownership. Boston, MA: Joint Center for Housing Studies of the MIT and Harvard University.

National Collaborative. 1992. Going National with HERS and EEMs: Issues and Impacts, The Collected Papers of the National Collaborative. (NREL/TP-261-4706) Golden, CO: National Renewable Energy Laboratory.

U.S. Department of Energy. 1991/1992. National Energy Strategy: Powerful Ideas for America. Washington, D.C.

Vories, R. and K. George. 1991. Analysis of Home Energy Rating Systems: Results of Brief Interviews. Denver, CO: Infinite Energy. 


\section{Appendixes}




\section{Appendix A: Existing Energy-Efficient Mortgage Programs}

\section{Introduction}

Energy bills are usually the largest portion of housing costs after rent or mortgage payments, averaging about $\$ 1,100$ a year - often twice that much in severe climates. For lower-income households, energy costs represent a proportionately greater fraction of the budget than for more affluent households. Although the energy efficiency of a typical residence could be improved, buyers of new or existing homes may not be able to afford the additional cost of energy improvements without mortgage incentives.

The energy-efficient mortgage (EEM) reduces homeownership costs by enabling homeowners to achieve meaningful energy savings with modest increases in mortgage payments. It allows the borrower to add the cost of energy measures to the mortgage, thereby providing the longer term, lower interest rate, and tax benefit of mortgage financing. The small increase in mortgage payments is typically more than offset by energy savings. In general, the EEM concept takes into account both the incremental capital cost and the reduced operating cost of an energy-efficient home.

Homes that are already energy efficient. An EEM allows more lenient rules in qualifying borrowers for mortgages on homes that meet certain levels of energy efficiency. Because the efficient home has lower energy bills, the borrower can spend a larger-than-normal portion of income on the basic mortgage payment. Although often applied to new construction and promoted through builders and their lenders, this EEM option is also available for existing energy-efficient homes.

Homes that require energy efficiency improvements. The other EEM option applies to the purchase or refinancing of existing homes that need energy upgrades.

In either case, the home becomes more affordable, as well as more comfortable and more valuable, with benefits to the buyers, seller, and lender. The EEM is a WIN-WIN-WIN concept.

\section{EEM Programs Available}

Several EEM programs have been implemented since 1980. National programs are available through three federal government organizations involved in home financing. In addition, the two major secondary mortgage lenders also have developed EEM programs.

All the EEM programs include guidelines to determine (a) whether the home meets the requisite level of energy efficiency, (b) which energy improvements may be added into the mortgage, and (c) how the limits on borrower qualification may be broadened to take reduced energy costs into account.

- The Federal Housing Administration (FHA) of the Department of Housing and Urban Development (HUD) insures home mortgages for qualifying home buyers. HUD/FHA allows an increase in the loan amount within certain limits and "stretches" the income qualifying ratios for mortgages on new homes meeting specific guidelines for energy efficiency.

- The Department of Veterans Affairs (DVA) guarantees mortgages for qualifying veterans with very little or no down payment, with the maximum loan amount determined by the participating lender. DVA allows an increase in the mortgage amount for energy-related improvements, within certain limits and with appropriate documentation.

\footnotetext{
"This material was prepared by the Office of Building Technologies, U.S. Department of Energy,
} November 1991. 
- The Farmers Home Administration (FmHA) does not have a specific category of energyefficient mortgages, but instead requires conformance with its thermal performance construction standards for all its loans, which are provided directly to qualifying borrowers in rural areas (under 10,000 population). FmHA will loan an additional amount for improvements, including those to increase energy efficiency, that are economically justified in accordance with "value-in-use" techniques.

- The Federal National Mortgage Association (FNMA or "Fannie Mae") and the Federal Home Loan Mortgage Corporation (FHLMC or "Freddie Mac") have developed criteria for home mortgages they are willing to buy and have promulgated these rules to their approved mortgage seller/servicer institutions, who in turn offer such loans to borrowers. Both encourage energy efficiency by providing specific criteria for EEMs they are willing to buy on the secondary mortgage market.

\section{Getting Started: Applying for an EEM}

An application for an energy-efficient mortgage should be directed to a local mortgage lender who participates in the EEM programs of a secondary mortgage lender (such as Fannie Mae or Freddie Mac) or an agency insuring or guaranteeing the mortgage, such as HUD/FHA or DVA, if applicable. A borrower does not apply through these organizations directly.

Because lenders process mortgages according to well-established procedures, timing is critical. Therefore, a borrower wishing to obtain an EEM should discuss this with the lender early in the mortgage application process. While shopping for a home, the borrower should identify a participating EEM lender and find out its specific requirements. If the home already meets an accepted energy efficiency standard, the purchaser should provide the documentation to the lender as soon as possible in the mortgage application process. A borrower hoping to finance energy conservation improvements as part of the mortgage will need to have the planned upgrades documented by an appraiser or energy consultant, as the lender requires, and installation will have to be completed within a required period of time.

\section{Sources of Information on Energy-Efficient Mortgages}

These sources are especially helpful for borrowers and lenders.

HUD/FHA: The booklet Guide to Single Family Home Mortgage Insurance (HUD-1235-H(2), April 1990), gives brief descriptions of the various HUD/FHA programs. HUD/FHA Mortgagee Letter 89-25 (October 20, 1989) states the HUD/FHA guidelines for approval of EEMs.

Contact the HUD Field Office nearest you, or the U.S. Department of Housing and Urban Development, Assistant Secretary for Housing/Federal Housing Commissioner, Washington, DC 20410-8000.

Department of Veterans Affairs: VA-Guaranteed Home Loans for Veterans (VA Pamphlet 26-4, August 1989), summarizes the eligibility criteria and application steps for VA loans in general. DVB Circular 26-80-31 (August 8, 1980; Change 3, December 10, 1985), Loans to Purchase Homes and Make Energy Conservation Improvements, states the modification of VA property valuation and loan processing procedures for including energy conservation improvements in loans for existing homes.

Contact the Loan Guaranty Division of the VA Regional Office in your state; these offices are listed in the pamphlet cited above.

Farmers Home Administration: Information on the FmHA loan program is available directly from the 2,200 local county and district FmHA offices, generally located in county seats of rural areas. 
Federal National Mortgage Association (Fannie Mae): A brochure, Energy Conservation Home Financing (January 1990), briefly describes the Fannie Mae EEM program. Product Highlights of August 1990, "Energy Conservation Home Financing," summarizes the EEM provisions contained in various sections of Fannie Mae's Selling Guide for approved lenders.

Contact the Fannie Mae Home Office, 3900 Wisconsin Avenue, NW, Washington, DC 20016-2899, or one of the five Regional Offices listed in Product Highlights.

Federal Home Loan Mortgage Corporation (Freddie Mac): Prospective borrowers should contact their local lender about Freddie Mac's EEM program.

For mortgage lenders, see Freddie Mac's Industry Letter, "Energy-efficient mortgage program and revised energy addendum" (July 21, 1989), which outlines the EEM program, including references to sections in Freddie Mac's Sellers and Servicers Guide. For a copy, contact your Freddie Mac marketing representative or Freddie Mac, 8200 Jones Branch Drive, McLean, VA 22102.

For more information: $\quad$ Contact NATAS, P. O. Box 2525, Butte MT 59702

$1-800-428-2525$

$1-800-428-1718$ (in Montana) 


\section{Appendix B: \\ Members of the National Collaborative}

Listed are members of the Collaborative Consensus Committee (CCC), members of the collaborative technical advisory committees, members of the CCC's Steering Committee, staff, and official observers.

\section{Collaborative Consensus Committee (CCC) Members}

Alliance to Save Energy (ASE) - Bill Prindle (Member), Washington, DC

American Association for Retired Persons (AARP) - George Gaberlavage (Member), Washington, DC; Jo Reed (Alternate), Washington, DC

American Gas Association (AGA) - Alan Hudenets (Member), Arlington, VA; Mary Carson (Alternate), Arlington, VA

American Public Power Association (APPA) - Barry Moline (Member), Washington, DC; Doug Swartz

(Alternate), Fort Collins, CO

American Society of Home Inspectors (ASHI) - Michael Lennon (Member), Falls Church, VA

Appraisal Institute (AI) - Steve Azia (Member), Washington, DC

Association of Energy Efficient Mortgage Service Companies (AEEMSC) - Jim Curtis (Member), Palo Alto, CA

California Home Energy Rating System, Inc. (CHERS) - Jim Fulkerson (Member), San Francisco, CA Consumer Federation of America (CFA) - David Swankin (Member), Washington, DC; Rebecca Cohen

(Alternate), Washington, DC

Edison Electric Institute (EEI) - Tom Farkas (Member), Washington, DC

Energy Efficient Builders Association (EEBA) - Don Buchan (Member), Ottawa, Ontario, Canada

Energy Rated Homes of America (ERHA) - Ron Hughes (Member), Little Rock, AR

Farmers Home Administration (FmHA) - Rich Davis (Member), Washington, DC

Federal Home Loan Mortgage Corporation (Freddie Mac) - Charles Fritts (Member), Washington, DC; Jane Stockinger (Alternate), McLean, VA

Federal National Mortgage Association (FNMA - Fannie Mae) - Chip Coffay (Member), Washington, DC

Federal Housing Administration (FHA) - Mark Holman (Co-Member), Washington, DC; Morris "Bud" Carter, (Co-Member), Washington, DC

Federal Institutions Examination Council, Appraisal Subcommittee - Ted Baker (Member), Washington, DC

Mortgage Bankers Association (MBA) - Bill Brewster (Member), Washington, DC

National Association of Home Builders (NAHB) - Perry Bigelow (Co-Member), Palatine, IL; Charles

Field (Co-Member), Washington, DC

National Association of the Remodeling Industry (NARI) - Patti Knoff-Burgio (Member), Arlington, VA National Association of REALTORSTM (NAR), Government Relations Division - Lee White (Member),

Washington, DC; George Griffin (Alternate), Washington, DC

National Association of State Energy Officials (NASEO) - Steve Baden (Co-member), Anchorage, AK;

Doug Culbreth (Co-member), Raleigh, NC; Chris Roitsch (Co-member), Austin, TX

Natural Resources Defense Council (NRDC) — Dan Lashof (Member), Washington, DC; Marika Tatsutani

(Alternate), Washington, DC

Southern Electric International, Good Cents Division - Benny Folsom (Member), Atlanta, GA

U.S. Department of Veterans Affairs (DVA) - Robert Finneran (Member), Springfield, VA 


\section{Technical Advisory Committee (TAC) Members}

\section{Home Energy Rating Systems (HERS) TAC}

CCC Co-Chair: Bill Prindle, Alliance to Save Energy, Washington, DC (now with Barakat and Chamberlin)

CCC Vice Chair: $\quad$ Steve Baden, National Association of State Energy Officials, Anchorage, AK

Staff Co-Chair: Ron Judkoff, National Renewable Energy Laboratory, Golden, CO

Members:

Tim Butler, Energy Division, North Carolina Department of Economic and Community Development, Raleigh, NC

William Freeborne, Policy Development and Research, U.S. Department of Housing and Urban Development, Washington, DC

Michael Holtz, Architectural Energy Corporation, Boulder, CO

Bion Howard, Alliance to Save Energy, Washington, DC

Steve Kennedy, Georgia Power, Atlanta, GA

Ron Nickson, National Association of Home Builders, Washington, DC

Doug Swartz, Light and Power Utility, City of Fort Collins (Co-member with IMP TAC), Fort Collins, $\mathrm{CO}$

Steve Szoke, Passive Solar Industries Council, Herndon, VA

\section{Energy-Efficient Mortgages (EEMs) TAC}

CCC Co-Chair: Bill Brewster, Mortgage Bankers Association, Washington, DC

Staff Co-Chair: Ken Crandall, Federal Housing Administration, Washington, DC

Members:

Richard Faesy, Energy Rated Homes of Vermont, Burlington, VT

Matt Felber, Farmers Home Administration, Washington, DC

Walter Patterson, Texas Energy Extension Service, Arlington, TX

William Sorrentino, National Association of Home Builders, Washington, DC

Jane Stockinger, Federal Home Loan Mortgage Corporation (Freddie Mac), McLean, VA

\section{Implementation TAC}

CCC Co-Chair: $\quad$ Charles Field, National Association of Home Builders, Washington, DC

Staff Co-Chair: $\quad$ Rebecca Cohen, Consumer Federation of America, Washington, DC

Members:

David Dacquisto, National Association of Home Builders, National Research Center, Upper Marlboro, MD Russell Duncan, Carolina Power and Light, Raleigh, NC

Javier Figueroa, Washington State Energy Office, Olympia, WA

Stuart Harshbarger, Washington Gas Light,

Doug Seiter, City of Austin, Austin, TX

Doug Swartz, Light and Power Utility, City of Fort Collins (Co-member with HERS TAC), Fort Collins, $\mathrm{CO}$

Richard Tracey, Ryland Homes, Columbia, MD 
Awareness TAC

CCC Co-Chair:

David Swankin, Consumer Federation of America, Washington, DC

Staff Co-Chair:

Gerry McGowan, Philadelphia Department of Energy Support Office, Philadelphia, PA

Members:

William Griffin, Commonwealth Edison, Chicago, IL

Deborah Howard, Arizona Energy Office, Tucson, AZ

Randy Martin, Iowa Department of Natural Resources, Des Moines, IA

Rebecca Vories, Infinite Energy, Denver, CO

Staff

U.S. Department of Energy (DOE)

John P. Millhone, Deputy Assistant Secretary, Office of Building Technologies, Washington, DC Mary-Margaret Jenior, Program Manager, Office of Building Technologies, Washington, DC

Gerry McGowan, DOE Philadelphia Support Office, Philadelphia, PA

National Renewable Energy Laboratory (NREL)

Barbara C. Farhar, HERS/EEMs Program Leader, Collaborative Co-Facilitator, Washington, DC

Ron Judkoff, Staff Co-Chair, HERS TAC, Golden, CO

Dorian McDuffie, Alyssa Tonelli, Kim Rattley, Conference Arrangements, Washington, DC

Lauren Raphael, Technical Writer, Washington, DC

Mary Anne Dunlap, Ann Brennan, Technical Editors, Golden, CO

Kay Vernon, Janet Fried, Word Processing, Golden, CO

Princeton Economic Research, Inc. (PERI)

Joseph M. Cohen, Minutes, Rockville, MD

U.S. Department of Housing and Urban Development (HUD)

Energy Division: Bob Groberg, Lois Dean, Observers, Washington, DC

Federal Housing Administration (FHA): Ken Crandall, Staff Co-Chair EEMs TAC, Washington, DC

Facilitator: John A.S. McGlennon, ERM-New England, Inc., Boston, MA

\section{Steering Committee Members}

Steve Baden, National Association of State Energy Officials, Anchorage, AK

Bill Brewster, Mortgage Bankers Association, Washington, DC

Rebecca Cohen, Consumer Federation of America, Washington, DC

Ken Crandall, Federal Housing Administration, Washington, DC

Barbara Farhar, National Renewable Energy Laboratory, Washington, DC

Mary-Margaret Jenior, U.S. Department of Energy, Washington, DC

Ron Judkoff, National Renewable Energy Laboratory, Golden, CO

Gerry McGowan, U.S. Department of Energy, Philadelphia Support Office, Philadelphia, PA

John Millhone, U.S. Department of Energy, Washington, DC

Bill Prindle, Alliance to Save Energy, Washington, DC

David Swankin, Consumer Federation of America, Washington, DC 


\section{Official Observers}

American Gas Association - Paul Cabot, Jane Marder, Bruce Savage, Arlington, VA

Appraisal Foundation - Deborah Sharp, Washington, DC

Appraisal Institute - Don Kelly, Washington, DC

Arizona Energy Office - Charles Gohman, Phoenix, AZ

Air Conditioning and Refrigeration Institute - Richard Denny, Arlington, VA

California Energy Commission - John Wilson, Sacramento, CA

City of Manassas - Randy Bowers, Manassas, VA

Communications Consulting - Laura Braustein, Reston, VA

Council of American Building Officials - Bob Spangler, Falls Church, VA

Electric Power Research Institute - Whitney Carroll, Michael Tinkleman, Washington, DC

Energy Efficient Builders Association - Bill Eich, Spirit Lake, IA

Energy Mines and Resources-Canada - Jack Cole, Ottawa, Ontario, Canada

Energy Rated Homes of America - Evan Brown, Dana Nixon, Little Rock, AR

Environmental Protection Agency - Adam Klinger, Washington, DC

Federal Home Loan Mortgage Corporation - Virgil Griffin, Washington, DC

Federal National Mortgage Association - John Nevin, Mark Simpson, Washington, DC

Florida Energy Office - Daryl O'Connor, Tallahassee, FL

Home Automation Association - Michael Coffey, Eric Davidson, Nick Pyle, Washington, DC

Independent Bankers Association - Marti Sworobuk, Washington, DC

Mineral Insulation Manufacturers Association - George Phelps, Alexandria, VA

Maryland Building Industries Association - Frank Merditch, Landover, MD

Mortgage Insurance Companies of America - Frank Balser, Washington, DC

National Association of REALTORSTM - Deborah Lassman, Steve O'Connor, Washington, DC

National Association of Regulatory Utility Commissioners - Michael Foley, Washington, DC

National Institute of Standards and Technology, Heat Transfer Group - Fanney Hunter, Bob Zarr,

Gaithersburg, MD

National Association of State Energy Officials - Frank Bishop, Washington, DC

National Energy Specialist Association - Frank Newbraugh, Topeka, KS

National Renewable Energy Laboratory - Ren Anderson, Golden, CO

Natural Resources Defense Council - Jennifer Jordan, Washington, DC

New York State Energy Office - David Abrey, Kevin O'Brien, Albany, NY

Pennsylvania Electric - Steve McDonnell, Montrose, PA

RISE - Deborah Curry, Providence, RI

The Society of the Plastics Industry, Inc. - George H. Sievert, Washington, DC

Southern California Edison - Gregg Ander, Rosemead, CA

U.S. Department of Energy - Ted Kapus, Sarah Kirchen, Simon Sidamon-Eristoff, Washington, DC

U.S. Department of Energy, New York Support Office - Joy Cazeaux, New York, NY

U.S. Department of Housing and Urban Development - Andrew Euston, Dick Manuel, Heidi Martin,

Roxanne Zimmerman, Washington, DC

U.S. Department of Veterans Affairs - Doug Widener, Washington, DC

U.S. Environmental Protection Agency - Adam Klinger, Washington, DC

U.S. League of Savings Institutions - Danielle French, Washington, DC

Vermont Housing Finance Agency - Doug Lothrop, Burlington, VT

Virginia Energy Office - Jim Smith, Richmond, VA 


\section{Appendix C Assigned Issues for the Technical Advisory Committees}

\section{Introduction}

Listed below is the final set of issues assigned by the Collaborative Consensus Committee to the Technical Advisory Committees.

\section{Assigned Issues}

\section{HERS Technical Advisory Committee}

Technical experts in home energy rating systems, energy auditing, energy-efficient design, and retrofits.

1. What studies show that home energy rating systems, where they have been applied, actually result in saved energy in residential buildings? Saved operating costs? If system did not result in energy savings, why not? If energy savings were realized, what were the contributing factors? (Ron Hughes)

2. Should alternative rating approaches be allowed, e.g., performance, prescriptive, utility bills, pass/fail, scaled, etc.? (Ron Hughes)

3. Upon what measures should the rating be based (Btu/year, Btu/ft $/ \mathrm{yr}, \mathrm{Btu} / \mathrm{ft}^{2} / \mathrm{DD}$, $\$ 1$, etc.)? Absolute measures, comparative measures, dollar savings, etc. (Ron Hughes)

4. What are the minimum guidelines to ensure technical credibility, uniformity, and allowance for local variations? (Michael Holtz)

5. What are the mechanisms for determining the accuracy of a rating system? (Ron Judkoff)

6. How does HERS industry deal with fuel neutrality? Can we develop a rating system that is not biased by fuel? If yes - what does TAC recommend? (Ron Hughes)

7. What information on behavioral patterns provides useful insights into how a HERS system might incorporate occupant behavior? (Michael Holtz)

8. How should HERS distinguish between new and existing homes? (Doug Swartz)

9. To what extent should there be linkage between HERS and EEMs? (Bill Prindle)

10. What information should HERS guidelines require vis-à-vis retrofits? Should the HERS give a dollar cost and saving by component of proposed retrofit? (Bill Prindle)

11. Are ratings required for each building, or can group ratings be permitted? (or subsets of ratings) (Bill Freeborne)

12. What building types should be included in HERS? (Stephen Szoke)

13. What features should be included in HERS? (Bion Howard)

14. What level of detail/accuracy is necessary? (Doug Swartz) 
15. How do we include innovative buildings/features in the HERS, yet keep it from being too cumbersome? (Ron Judkoff)

16. What are the minimum required outputs from HERS tools? (Ron Hughes)

17. To what extent should HERS be linked to state and local codes? (Ron Nickson)

18. Under what conditions is re-rating required? (Steve Baden)

19. Should there be a national threshold for qualifying for an EEM? If not, how will local thresholds be decided? (Bill Prindle)

\section{EEMs Technical Advisory Committee}

Technical experts in mortgage financing, real estate, appraisal, housing, law, and administrative requirements.

1. What data or analyses do we have showing that energy-efficient mortgages increase housing affordability? (e.g., if increased mortgage expense is offset by decreased operating expense, how does the home owner come out ahead financially?) Do any field data or analyses demonstrate how the homeowner benefits? How many more households might qualify for housing? What analyses have been done (or need to be done) on the impact of energy-efficient mortgages on portfolio risk? (Bill Brewster)

2-5. Is it desirable to have a uniform EEM program and, if so, what are its characteristics? What underwriting rules should apply to EEMs? What should qualifying ratios be? Should a ratio stretch or a PITI + E approach be used? If the debt-to-income ratios are increased for mortgagees having energy-efficient housing, what should the ratios be? One specific amount or scaled to reflect the building's energy performance? or income level? What should the ratios be for given household incomes and/or building energy performance levels? (Walter Patterson and Bill Brewster - 2 papers)

6. What would a uniform appraisal/valuation method be? How does one measure the value of energy-efficiency improvements? How should they be accounted for in the appraisal process? What data or analyses have been done (or are needed) on the impact of energy improvements on resale value of house? (Bill Brewster)

7. For an existing home, what should the total amount of energy improvements be? (Jane Stockinger)

8. What should the total loan-to-value ratio of EEMs be? (Jane Stockinger)

9. For existing mortgages, how can energy-efficiency improvements be financed as part of the mortgage? (Jim Curtis)

10. How can the EEM process be designed to avoid delay in the process? (The EEMs TAC will deal with the mechanics of what can be done; the IMP TAC will deal with who should do it.) (Richard Faesy)

11-12. What kind of information is needed by lenders to trigger an energy-efficient mortgage? What basic quantities do the mortgage lenders need from the HERS? (Chip Coffay - lender perspective; Tom Farkas - HERS perspective) 
13. What alternatives to escrow arrangements can be considered? Would a trustee system for fees, escrow accounts, and savings guarantees be beneficial? (Jim Curtis)

14. How might inducements (such as rebates) be treated within an EEM process? When would such inducements be available? (Ken Crandall)

\section{Implementation Technical Advisory Committee}

Technical experts in utility programs, state energy programs, home inspection, remodeling, impact assessment, management analysis, cost/benefits analysis, and legal analysis.

1. What alternative institutional arrangements are possible to implement HERS/EEMs? For example, should HERS/EEMs be delivered through state programs? Through utilities?

What alternative strategies at the federal, state, regional and local level are required to implement a uniform national energy-efficient mortgage program linked to a voluntary home energy rating system process? Whose participation is required at each level?

(Consider the whole range of HUD and USDA community development and housing programs: those of local Home Builder Associations (HBAs); local government housing, code enforcement and community planning and development programs, better housing organization and other social service agency activities; housing and planning programs of regional councils of government (COGs); utility audit and DSM/rebate programs; and the roles of state community affairs, housing and energy agencies, national trade and professional associations, and federal regional offices.)

How can the strategies identified and existing utility, HBA, local or state government energyefficiency mortgage and home energy rating system programs be effectively linked? (Don Buchan)

2. (With respect to existing buildings.) What are the estimated costs to each actor associated with implementing the various alternatives? What existing data or other measures were used to make these cost estimates? How might these costs be financed? What might the financial impact be on home buyers? state budgets? local budgets? taxpayers? utility rates and stockholders? others? (e.g., who will win and who will lose, if anyone?)

What empirical evidence is there on which to base estimates of the costs involved in implementing a nationwide HERS/EEMs system? What financial resources would be necessary to implement HERS/EEMs? What are programs going to cost at local, state, and federal levels? (Frank Newbraugh)

3. (With respect to new buildings.) Same question as 2. (Richard Tracey)

4. What would consumer impacts be? What are consumer protection issues, and how can they be prevented? (Rebecca Cohen)

5. How can consumer protection issues be resolved? (Rebecca Cohen)

6. What are liability issues and options? (Benny Folsom)

7. What human resources would be necessary for implementation? (Doug Seiter) 
8. What role might the states play, and what incentives might be needed to encourage states to participate in a national system or program? (Chris Roitsch)

9. What incentives are needed to encourage local participation? (Russell Duncan)

10. What are the actions necessary for quality control, who would carry them out, and what would be the estimated costs? (Barry Moline)

11. Who should verify the adequacy/accuracy of building energy predictive tools? (Barry Moline)

12. What aspects of a combined HERS/EEMs program might be mandatory? (Doug Culbreth)

13. What are the roles of the various participants in avoiding delay in the loan approval process? (related to EEMs Issue \#10) (Javier Figueroa)

\section{Awareness Technical Advisory Committee}

Technical experts in marketing, advertising, consumer protection, training, needs assessment, and education.

1. Generation and distribution of HERS/EEMs information for consumers and shelter industry audiences. (Rebecca Vories)

2. What are the informational needs of the following groups? (Deborah Howard)

- Mortgage lenders

- Appraisers

- Inspectors

- Real estate agents

- Code officials

- Energy auditors

- Builders

- Remodelers /retrofitters

- Dealers

- Manufacturers of manufactured homes

- Product suppliers and manufacturers

- Organized consumer advocacy groups

- Utilities

- Organized energy and environmental advocacy groups

- Regulators

- Relocation companies

- Real estate attorneys

- Homeowner associations

- State and local executives and legislative bodies

3. What are the motivational needs of the following groups? (Refer to groups listed for item 2). What are the technical needs of the following groups? (Refer to groups listed for item 2) (Deborah Howard)

4. What are the information and education needs of consumers and how can they best be met? What are the components of an objective consumer education program for HERS/EEMs? (Gerry McGowan) 
5. What provision will be made for technical assistance? (Randy Martin)

6. What are the best "trigger points" for awareness in the new and resale home sales processes? How can these be activated? (Dave Swankin)

- Time of contract signing

- Time of mortgage application

- Time of listing home

- Time of home inspection

- Time of multiple listing

- Utility bill insert

- Real estate agent promotional mailings

- Time when consumers first consider buying, selling, or refinancing home

- Time of remodeling, retrofitting, or major repair

- Time of refinancing for any reason

7-8. What types of labeling will be best in terms of helping promote awareness? What type of labeling, if any, will be best in terms of helping promote awareness? What are the criteria for evaluating a "good" label? (Bill Griffin/David Swankin) What labeling should be requied for a home energy rating? (Bill Prindle) What kinds of public information should a program implementating organization commit itself to disclose? [Merged into issues 1-3 and 6.]

9. What proficiency requirements should there be for raters and anyone making calculations on retrofits? (Mike Lennon) 


\section{Appendix D: National Collaborative Schedule}

Phase I-Education

Phase II-Consensus Decision Making

\begin{tabular}{|l|c|c|c|c|c|c|c|c|c|}
\hline & $\begin{array}{c}\text { April } \\
1991\end{array}$ & $\begin{array}{c}\text { May } \\
1991\end{array}$ & $\begin{array}{c}\text { June } \\
1991\end{array}$ & $\begin{array}{c}\text { July } \\
1991\end{array}$ & $\begin{array}{c}\text { September } \\
1991\end{array}$ & $\begin{array}{c}\text { October } \\
1991\end{array}$ & $\begin{array}{c}\text { November } \\
1991\end{array}$ & $\begin{array}{c}\text { December } \\
1991\end{array}$ & $\begin{array}{c}\text { January } \\
1992\end{array}$ \\
\hline $\begin{array}{l}\text { Collaborative } \\
\text { Consensus } \\
\text { Committee }\end{array}$ & $\Delta(3 / 26)$ & $\Delta$ & $\Delta$ & $\Delta$ & $\Delta$ & $\Delta$ & $\Delta$ & $\Delta \Delta$ & $\Delta$ \\
\hline $\begin{array}{l}\text { HERS } \\
\text { Technical } \\
\text { Advisory } \\
\text { Committee }\end{array}$ & & $\Delta$ & $\Delta$ & $\Delta$ & $\Delta$ & & & \\
\hline $\begin{array}{l}\text { EEMs } \\
\text { Technical } \\
\text { Advisory } \\
\text { Committee }\end{array}$ & & & $\Delta$ & $\Delta$ & $\Delta$ & $\Delta$ & & & \\
\hline $\begin{array}{l}\text { Implementation } \\
\text { Technical } \\
\text { Advisory } \\
\text { Committee }\end{array}$ & & & $\Delta$ & $\Delta$ & $\Delta$ & $\Delta$ & & & \\
\hline $\begin{array}{l}\text { Awareness } \\
\text { Technical } \\
\text { Advisory } \\
\text { Committee }\end{array}$ & & & $\Delta$ & $\Delta$ & $\Delta$ & $\Delta$ & & & \\
\hline
\end{tabular}




\section{Appendix E: Acronyms}

\begin{tabular}{|c|c|}
\hline AARP & American Association for Retired Persons \\
\hline A-EEM-SCOs & Association of Energy Efficient Mortgage Service Companies \\
\hline AFUE & annualized fuel utilization efficiency \\
\hline AGA & American Gas Association \\
\hline AI & The Appraisal Institute \\
\hline APPA & American Public Power Association \\
\hline ASE & Alliance to Save Energy \\
\hline ASHI & American Society of Home Inspectors \\
\hline ASHRAE & American Society of Heating, Refrigerating, and Air-Conditioning Engineers \\
\hline $\mathrm{CABO}$ & Council of American Building Officials \\
\hline $\mathrm{CCC}$ & Collaborative Consensus Committee \\
\hline $\mathrm{CE}$ & Office of Conservation and Renewable Energy (within DOE) \\
\hline CFA & Consumer Federation of America \\
\hline CFR & Code of Federal Regulations \\
\hline CHERS, Inc. & California Home Energy Rating System, Inc. \\
\hline COP & coefficient of performance (ratio of heat delivered to energy consumed) \\
\hline DOC & U.S. Department of Commerce \\
\hline DOE & U.S. Department of Energy \\
\hline DSM & demand-side management \\
\hline DVA & U.S. Department of Veterans Affairs \\
\hline EEBA & Energy Efficient Builders Association \\
\hline EEI & Edison Electric Institute \\
\hline EEMs & energy-efficient mortgages \\
\hline EER & energy-efficient ratio \\
\hline EMV & energy mortgage valuation \\
\hline EPA & U.S. Environmental Protection Agency \\
\hline EPRI & Electric Power Research Institute \\
\hline ERHA & Energy Rated Homes of America \\
\hline FHA & Federal Housing Authority \\
\hline FHLMC & Federal Home Loan Mortgage Company (Freddie Mac) \\
\hline FIEC & Federal Institutions Examination Council \\
\hline FmHA & Farmers Home Administration \\
\hline FNMA & Federal National Mortgage Association (Fannie Mae) \\
\hline FTC & Federal Trade Commission \\
\hline GNMA & Government National Mortgage Association \\
\hline GPO & Government Printing Office \\
\hline GRI & Gas Research Institute \\
\hline GSA & General Services Administration \\
\hline HBAs & Home Builder Associations \\
\hline HBI & Home Builders Institute \\
\hline HDD & heating degree days \\
\hline HERS & home energy rating system(s) \\
\hline HUD & U.S. Department of Housing and Urban Development \\
\hline HVAC & heating, ventilating, and air conditioning \\
\hline IAQ & indoor air quality \\
\hline $\mathrm{kW}$ & kilowatt \\
\hline $\mathrm{kWh}$ & kilowatt-hour \\
\hline LCC & life-cycle costing \\
\hline LTV & loan-to-value ratio \\
\hline MBA & Mortgage Bankers Association of America \\
\hline MCS & Model Conservation Standards \\
\hline
\end{tabular}




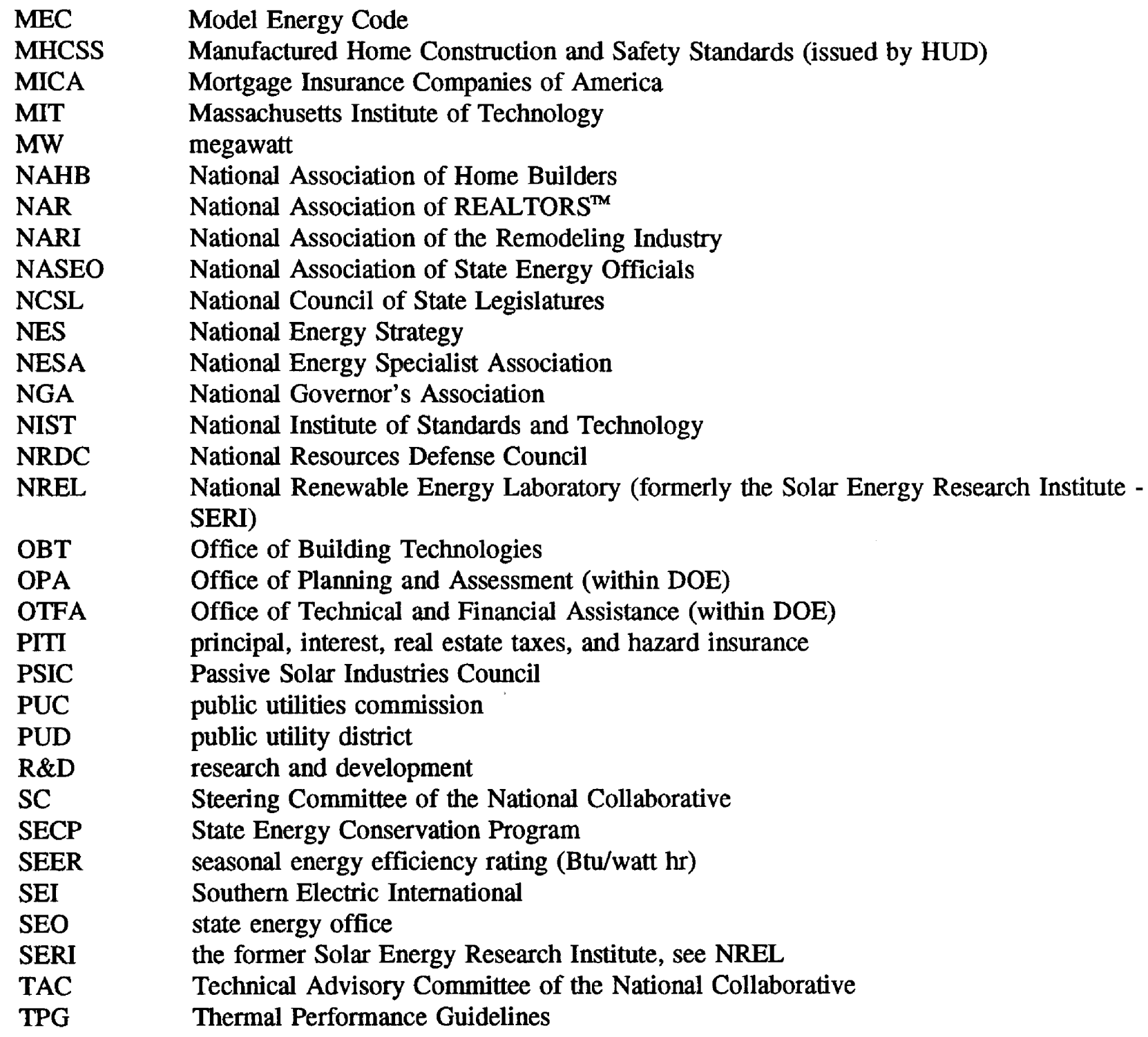




\section{Glossary}

Amortization - Gradual payoff of a debt through installment payments of principal and interest. Most modern mortgages amortize monthly over the term of the loan.

Annual energy cost savings - The difference in the first year cost of energy of the proposed or existing building or facility as compared with the energy cost of its representative structure.

Applicant - A prospective mortgage borrower.

Appraisal - A report made by a qualified person setting forth an opinion or estimate of value. The term also refers to the process by which this estimate is obtained. In conventional mortgages and in the HUD-FHA Direct Endorsement program, the lender receives a copy of the complete report, showing the basis for the appraiser's estimate. In VA cases and in HUD applications processed by HUD, the lender receives only a statement of the estimate of value, without any detailed supporting data.

Appraised value - An opinion of value reached by an appraiser based upon knowledge, experience, and a study of pertinent data. Distinguished from FHA value.

Appraiser - Person who gathers information about a home that is necessary to rate the energy efficiency of the home.

Appreciation - Any increase in value. The opposite of depreciation.

Audit - Analysis of a specific building's consumption and potential to conserve utility-supplied energy. An energy inspection typically associated with utility RCS (Residential Conservation Service) audits, which were mandated by Congress for larger utilities to provide until July 31, 1990.

Baseline - The point from which energy savings are measured.

Basic qualifying ratio - The maximum generally acceptable qualifying ratio for a mortgage agency; e.g., for Fannie Mae and Freddie Mac, it is presently 28/36. This ratio is often adjusted upward or sometimes downward for compensating factors such as the borrower's credit worthiness.

Borrower - A mortgagor who receives funds in the form of a loan with the obligation of repaying the loan in full with interest, if applicable.

British thermal unit (Btu) - A unit used to measure quantity of heat, defined as the quantity of energy necessary to raise the temperature of $1 \mathrm{lb}$ of water $1^{\circ}$ Fahrenheit.

Btu/ft $\mathbf{t}^{2}$ - Energy consumption unit per square foot of building floor space.

Building code - The local regulations that control design, construction, and materials used in construction. Building codes are usually based on safety and health standards.

Calculational systems - Systems usually based on one of the many building simulation models and an estimate of the amount of energy saved over some base case, which might be the current building code. The savings are translated into several forms: $\mathrm{Btu} / \mathrm{ft}^{2}$, points which are equivalent to a certain amount of usage/savings, or other designations such as "stars." 
Certification programs - A program typically operated by utilities, home builders' organizations, or notfor-profit organizations representing interest parties. Energy efficiency standards are developed using local area demographics construction practices and area climatic conditions. They usually include thermal envelope efficiency criteria and space conditioning efficiency criteria. Certification programs generally rely on a specified inspection/verification process to ensure rating consistency. Houses either pass or fail the inspection for energy efficiency.

Climate zone (CZ) - One of 16 geographic zones in California, defined by the California Energy Commission as having similar typical weather patterns. Climate zones are used to determine annual energy use in buildings in each climate zone.

Closing - The conclusion of a transaction. In real estate, closing includes the delivery of a deed, financial adjustments, the signing of notes, and the disbursement of funds necessary to the sale or loan transaction.

Comparables - An abbreviation for comparable properties used for comparative purposes in the appraisal process. Refers to facilities of reasonably the same size and location with similar amenities. Also properties that have been recently sold and have characteristics similar to the property under consideration, thereby indicating the approximate fair market value of the subject property.

Compensating factors - Any underwriting consideration that would justify the use of higher debt-toincome qualifying ratios. Examples are large downpayment, excellent credit history, or a demonstrated ability to accumulate savings.

Consensus - Informal, face-to-face interaction among specially chosen representatives of all "stakeholding" groups; a voluntary effort to seek "all gain" rather than "win-lose" solutions or watered-down political compromise; often requires the assistance of a neutral facilitator or mediator.

Conventional loan - A mortgage loan neither insured by HUD/FHA nor guaranteed by VA or the Farmers Home Administration.

Cost effective - Producing the most economical outcome for consumers.

Debt - A sum of money due by certain and express agreement.

Debt/equity ratio - A ratio between the amount of capital borrowed and the amount of capital invested out-of-pocket or obtained through the sale of common stock; also known as the leverage ratio.

Debt-to-income ratio - See Qualifying ratio.

Debt-to-income ratio increase - see Ratio increase.

Default - A breach or nonperformance of the terms of a note or the covenants of mortgage.

Efficiency - The ratio of the useful energy delivered by a dynamic system (such as machine, engine, or motor) to the energy supplied to it over the same period or cycle of operation. The ratio is usually determined under specific test conditions.

Energy - The capacity for doing work. Forms of energy include thermal, mechanical, electrical, and chemical. Energy may be transformed from one form into another. 
Energy cost savings - The difference between a home whose energy costs are being measured and a comparable home with no energy-saving construction or improvement features. For an existing energy-inefficient home, it is the difference in operating cost between the home as it exists and the home after it has received energy-saving improvements.

Energy-efficient measures - Items that reduce a home's consumption of utility-supplied energy, including measures such as insulation and low-emissivity windows and renewable energy technologies such as passive solar design and solar domestic hot water systems.

Energy-efficiency rating - A certification of a home's energy efficiency or a relative indication of its energy efficiency on a graduated scale.

Energy-efficient mortgages (EEMs) - When a homeowner or home buyer applies for a home loan, at the time of purchase or refinance, he or she can roll the cost of needed energy improvements into the mortgage, amortizing the cost of the improvements over the life of the mortgage.

Energy-efficient mortgage program - The energy improvement programs of the VA, FHA, Fannie Mae, Freddie Mac, and the Farmers Home Administration. These are national programs that are available to all home buyers and homeowners at the time of purchase or refinance.

Energy label - Label or sticker placed on the home's energy meter stating energy efficiency rating of home.

Energy rating - A designation of the relative efficiency of a property. In a larger sense, the rating would also include a prioritized energy improvement recommendation, estimates of energy and dollar savings, and documentation of efficiency and savings for the loan file if completed in conjunction with energy-efficient mortgages.

Energy-saving construction or improvement features - Features that contribute to the lowering of energy use in a residence. They include, but are not limited to the following: insulation (e.g., wall, ceiling, floor, slab, crawl, basement, window, door); air infiltration reduction (e.g., gaskets, caulking, weatherstripping, controlled mechanical ventilation); heating and cooling equipment (e.g., setback thermostats and high-efficiency furnace, air conditioner, water heater, and fireplace); duct loss reduction; glazing (e.g., amount of glazing, R-value, solar fraction, solar orientation); and passive and active solar features.

Energy-saving measure - Any device, equipment, material, process, construction method, system, structure or combination thereof that will result in a reduction of energy usage, when compared with conventional energy-related practice in the area of the project.

Equity - Net ownership; the difference between fair market value and current indebtedness, usually referred to as the owner's interest.

Escrow - (1) A transaction in which a third party, acting as the agent for the buyer and seller, carries out instructions of both and assumes the responsibilities of handling all the paperwork and disbursement of funds in a transfer of title and mortgage loan transaction. Escrows may also be established for any purpose, at any time, as for example, in the administration of funds set aside to effect a "buydown" agreement among seller, buyer, and lender. (2) Funds included in the monthly mortgage payments to accumulate amounts necessary to pay property taxes, insurance premiums, etc. in the future are held in escrow, but the lender often acts as the escrow agent, especially if the lender is a depository institution. 
Escrow account - The segregated trust account in which escrow funds are held. The term is also used to describe the accounting of such funds.

Escrow arrangements - Procedures followed and agreements made in conjunction with establishing and scheduling disbursements from an escrow account.

External load controls - Fixed or movable shading elements (e.g., awings, wing walls, overhangs, eaves, shade screens) that control solar heat gain to exterior envelope components.

Fannie Mae - Term commonly used in referring to the Federal National Mortgage Association.

Farmers Home Administration (FmHA) - A government agency within the Department of Agriculture that operates under the Consolidated Farm and Rural Development Act of 1921 and Title V of the Housing Act of 1949. This agency provides financing to farmers and other qualified borrowers who are unable to obtain loans elsewhere.

Federal Home Loan Mortgage Corporation (FHLMC) - A quasi-government agency that purchases conventional mortgages in the secondary mortgage market from insured depository institutions and HUD-approved mortgage bankers. It sells mortgage participation certificates (PCs) secured by pools of conventional mortgage loans. Popularly known as Freddie Mac.

Federal Housing Administration (FHA) - A division of the Department of Housing and Urban Development. Its main activity is the insuring of residential mortgage loans made by private lenders. It sets standards for construction and underwriting. FHA neither lends money, plans, nor constructs housing.

Federal National Mortgage Association (FNMA) - A congressionally chartered corporation with private stockholders, that purchases residential mortgages insured by FHA or guaranteed by VA, as well as conventional home mortgages. Popularly known as Fannie Mae.

Freddie Mac - Term commonly used in referring to the Federal Home Loan Mortgage Corporation.

Fuel neutral - Rating system that factors in heating and cooling equipment efficiency without favoring one energy type or technology.

Hazard insurance - A contract whereby an insurer, for a premium, undertakes to compensate the insured for loss on a specific property due to certain hazards.

Heating, ventilating, and air conditioning system (HVAC) - A system that provides heating, ventilating, and/or cooling within or associated with a building.

Home energy rating systems (HERS) - HERS measure and rate, on a scale, the relative energy efficiency of any house, regardless of age, efficiency, or fuel use. The rating is based on the efficiency of the thermal envelope and the heating, ventilating, and air conditioning (HVAC) system and is obtained by on-site inspection and calculations. HERS calculations include estimates of annual energy performance and costs and recommendations for cost-effective energy efficiency improvements. 
HERS characteristics - (1) Designed to rate, on a scale, the relative energy efficiency of any house-new and existing, efficient and inefficient; (2) provides a rating based on efficiency of the thermal envelope, space heating and cooling efficiency, and water-heating efficiency; (3) estimates annual costs; (4) recommends improvement measures; (5) is fuel neutral; (6) requires on-site inspections and quality control; (7) typically, is state sponsored (or approved) and third-party delivered; (8) has goal of providing voluntary, market-driven incentives to encourage increased efficiency; (9) provides documentation that a house meets or exceeds a minimum standard for efficiency designated at a point on the scale.

Home energy rater - The person trained and possibly certified to inspect a residence to collect all information needed to complete a home energy rating.

Housing and Urban Development, Department of (HUD) - The Department of Housing and Urban Development was established by the Housing and Urban Development Act of 1965 to supersede the Housing and Home Finance Agency and give Cabinet status to the administration of the nation's housing and urban development programs. It is responsible for the implementation and administration of government housing and urban development programs. The broad range of programs includes community planning and development, low-rent public housing, mortgage insurance for residential mortgages (FHA), equal opportunity in housing, and research and technology.

Indemnify - To protect against loss or damage; insure. To make compensation to for loss or damage.

Insulation, thermal - A material having a relatively high resistance of heat flow and used principally to retard heat flow.

Loan-to-value ratio (LTV) - (1) The relationship between the amount of the mortgage loan and the appraised value of the security, expressed as a percentage of the appraised value. (2) In HUD-FHA transactions, the relationship between the amount of the mortgage loan and "FHA value," which is the sum of the appraised value of the property and the estimated closing costs. See also FHA value.

Low-e - A special coating that reduces the emissivity of a window assembly, thereby reducing the heat transfer through the assembly.

Manufactured house - see Modular house and Mobile home.

Market value - The most probable price that a property should bring in a competitive and open market under all conditions requisite to a fair sale, the buyer and seller each acting prudently and knowledgeably, and assuming the price is not affected by lender stimulus.

Mechanical systems - See Heating, ventilating and air conditioning (HVAC) system.

Mobile home - A factory-assembled residence consisting of one or more modules in which a chassis and wheels are an integral part of the structure and that can be made ready for occupancy without removing the chassis and/or wheels. See also Modular house.

Modular house - A factory-assembled residence built in units or sections, transported to a permanent site, and erected on a foundation. The term excludes mobile homes. See also Mobile home. 
Mortgage - A conveyance of an interest in real property given as a security for the payment of a debt. In its simplest form, the mortgage permits foreclosure if the debt is not paid, but the foreclosure is usually a judicial proceeding, in court. After foreclosure, the property is then sold, usually by an officer of the court, to satisfy the debt.

National/ocal threshold - That point on the uniform scale at which energy-efficient mortgage benefits kick in. This would be a national threshold if it is set nationally, a local threshold if it is set locally.

Passive solar gain - Solar energy that enters the building, providing heating and/or daylighting to the building.

Passive solar technologies - Technologies that combine architecture to benefit from solar radiation incidence on buildings for heating, cooling and lighting, with good conservation techniques for the building envelope and energy-efficient equipment and controls. Passive solar technologies are typically sunspaces, direct gain systems, and thermal storage wall systems.

Pass/fail rating - A rating system in which an appraised home will "pass" if it meets or exceeds a predetermined level of energy efficiency.

PITI - Principal, interest, taxes, and insurance.

PITI + E - A borrower qualification method that incorporates energy efficiency in the debt-to-income ratios by adding the energy operating cost for the candidate house to other elements of the housing expense.

PITI - ES - A borrower qualification method that incorporates energy efficiency in the debt-to-income ratios by deducting the energy cost savings of the candidate house from other elements of the housing expense.

Principal - The amount of debt, exclusive of accrued interest remaining on a loan. Before any principal has been repaid, the total loaned amount is the principal.

Private mortgage insurance - Insurance written by a private company protecting the mortgage lender against loss occasioned by a mortgage default.

Processing - The preparation of a mortgage loan application and supporting documents for consideration by a lender or insurer.

Quality assurance - A system of controls and actions that ensure and verify conformity (within agreed upon tolerance) to a set of values, norms, standards, or expectations established by a recognized authority.

Qualifying ratio - Percentage ratios that compare the borrowers' anticipated monthly fixed housing expense and total monthly obligations to the borrowers' stable monthly gross income for the purpose of evaluating the likelihood of meeting expenses involved in homeownership.

Rater - A person trained and certified to complete energy ratings of buildings under an approved rating system.

Rating - A designation of a specific home on a rating scale designed to communicate its level of energy efficiency. 
Rating tool - A certified procedure for calculating total annual energy consumption and costs of a home and for assigning a rating that establishes how a given home compares with the efficiency of all other homes.

Ratio increase - The process of increasing the standard debt-to-income ratio in the mortgage transaction by an incremental addition based on favorable financial attributes of a particular borrower.

Refinancing - The repayment of a debt from the proceeds of a new loan using the same property as security.

Remodeling - Additions, modernization.

Renewable energy technologies - The use of, as resources, the energy inherent in sunlight and the direct and indirect results of its impact on our planet (photons, wind, falling water, temperature differentials, and plant matter), gravitational forces (the tides), and the Earth's heat. These technologies at the sites of homes tend to be limited to: passive solar space heating, cooling, and lighting; solar water heating; active solar space heating; photovoltaic generation of electricity; biofuel appliances; and wind generation of electricity.

Renovation - Major rebuilding of existing building.

Retrofit - A modification to an existing building. An energy retrofit is a retrofit that affects the energy performance of the building.

Risk - Two kinds of risk are recognized by the mortgage-lending community: (1) underwriting risk-the degree of probability of default by a borrower; and (2) default risk - the amount or quantity of loss due to default or nonpayment.

Scoring system - A rating system in which points can be obtained for particular levels of various energy efficiency features.

Secondary mortgage market - A system whereby lenders and investors buy existing mortgage or mortgage-backed securities and in doing so provide greater availability of funds for additional mortgage lending by banks, mortgage bankers, and savings and loan associations.

Stretch mortgages - Enhanced qualification ratios.

Submetering - Breaking down the utility metering of a building to determine the proportionate energy use of specific building systems and appliances.

System - A combination of equipment and/or controls, accessories, interconnecting means, and terminal elements by which energy is transformed to perform a specific function, such as climate control, service water heating, or lighting (see California Code of Regulations, Title 24, Section 2-5302).

Temperature - Degree of hotness or coldness measured on one of several arbitrary scales based on some observable phenomenon (such as the expansion of mercury).

Thermal envelope - The building's shell-walls, foundation, floors, ceiling, windows, doors, and roof.

Thermostat - An automatic control device designed to be responsive to temperature and typically used to maintain set temperatures by cycling the heating, ventilating, and air conditioning system.

Third party - An individual or group that does not have any financial interest in the mortgage transaction. 
Title - The evidence of the right to or ownership in property. In the case of real estate, the documentary evidence of ownership is the title deed that specifies in whom the legal estate is vested and the history of ownership and transfers. Title may be acquired through purchaser, mortgagee, or otherwise.

Underwriting - The analysis of risk and the matching of it to an appropriate rate and term. Underwriting involves an analysis of the property, as revealed in the appraisal report, as acceptable and adequate security for the loan and an analysis of the borrower's ability and probable willingness to repay the loan. Risk may also be affected by other factors, such as loan-to-value ratios, the presence or absence of mortgage insurance, etc.

Uniform - Common, standardized, with no variations in material characteristics.

Utility audit - A formal review of a house's energy use conducted by a utility company representative, with recommendations for energy-efficiency measures, such as weatherstripping, caulking, and insulation.

Valuation - Estimation of value or price though appraisal.

Veterans Administration (VA) - An independent agency of the federal government created in 1930. The Servicemen's Readjustment Act of 1944 authorized the agency to administer a variety of benefit programs designed to facilitate the adjustment of returning veterans to civilian life. The VA home loan guaranty program is designed to encourage lenders to offer long-term, low-downpayment mortgages to eligible veterans by guaranteeing the lender against loss. VA losses, if any, are paid with the appropriated funds. The VA is now the U.S. Department of Veterans Affairs (DVA).

Whole-house fan - A system capable of cooling a house by exhausting a large volume of warm air when outside air is cool. 